\title{
MATERIAŁOWE TENDENCJE ROZWOJOWE ŁOPATEK TURBIN SILNIKÓW LOTNICZYCH NA PRZYKŁADZIE DTSO RD-33
}

\author{
AdAM KOZAKIEWICZ \\ Wojskowa Akademia Techniczna, Wydzial Mechatroniki i Lotnictwa, Instytut Techniki Lotniczej, Warszawa \\ e-mail: adam.kozakiewicz@wat.edu.pl \\ STANISŁAW JÓŹWIAK \\ Wojskowa Akademia Techniczna, Wydzial Nowych Technologii i Chemii, Instytut Inżynierii Materiałowej, Warszawa \\ PRZEMYSEAW JÓŹWIAK \\ Instytut Techniczny Wojsk Lotniczych, Warszawa \\ STANISŁAW KACHEL \\ Wojskowa Akademia Techniczna, Wydział Mechatroniki i Lotnictwa, Instytut Techniki Lotniczej, Warszawa
}

Artykuł dotyczy analizy żarowytrzymałych nadstopów przeznaczonych na łopatki lotniczych turbin gazowych. Wieloletni rozwój tych materiałów ma na celu przede wszystkim wzrost odporności termicznej umożliwiajacej podnoszenie osiągów silników dzięki wzrostowi temperatury gazów spalinowych przed turbiną. Można zauważyć możliwości materiałowe, aczkolwiek coraz wyższe z upływem czasu, pozostaja jednak wciąż wiele do życzenia z punktu widzenia konstruktorów silników. Głównym celem artykułu było określenie zamienników materiałowych tworzywa konstrukcyjnego użytego na łopatki turbin silnika RD-33, poprzez analizę komercyjnych i ogólnie dostępnych żarowytrzymałych nadstopów. Dzięki wcześniejszym pracom zespołu określono materiał, z jakiego wykonane zostały łopatki turbiny silnika RD-33, a dzięki znajomości jego właściwości mechanicznych wyznaczonych w badaniach materiałowych możliwym był dobór zamienników materiałowych o lepszych właściwościach użytkowych, głównie wytrzymałościowych. Do tego celu użyty został program CES EduPack.

Słowa kluczowe: turbinowy silnik odrzutowy, badania materiałowe, stopy żarowytrzymałe

\section{Wstęp}

Cytując za prof. A. Maciejnym [1] można stwierdzić, iż przemysł lotniczy jest nader ważnym inkubatorem nowoczesnych stopów metalicznych. Przykładem są żarowytrzymałe nadstopy przeznaczone do budowy łopatek lotniczych turbin gazowych, których skład chemiczny jest doskonalony od sześćdziesięciu lat. Potwierdzeniem powyższego stwierdzenia może być analiza liczby publikacji dotyczących rozwoju tych materiałów sporządzona na podstawie danych zawartych w bazie Elsevier (rys. 1).

Łatwo można zauważyć wyraźny progres w liczbie publikacji, a tym samym wzrost zainteresowań odbiorców stymulujących konieczność badań naukowych w zakresie rozwoju materiałów stosowanych na łopatki turbin gazowych, w czym niebagatelny, bo około 30\% udział posiadają materiały stosowane do budowy łopatek lotniczych silników odrzutowych. Materiały te, ze względu na warunki pracy cechować się muszą odpowiednią żaroodpornością i żarowytrzymałością prowadzącej do uzyskania odpowiedniej wytrzymałości na pełzanie. Dlatego też wieloletni

\footnotetext{
${ }^{1}$ Rysunki zaczerpnięte ze źródeł angielskojęzycznych, z podaniem źródła, pozostawiono z oryginalnymi opisami. Według autorów i ogólnie przyjętych zasad materiały źródłowe nie powinny być przerabiane bez zgody ich autorów.
} 


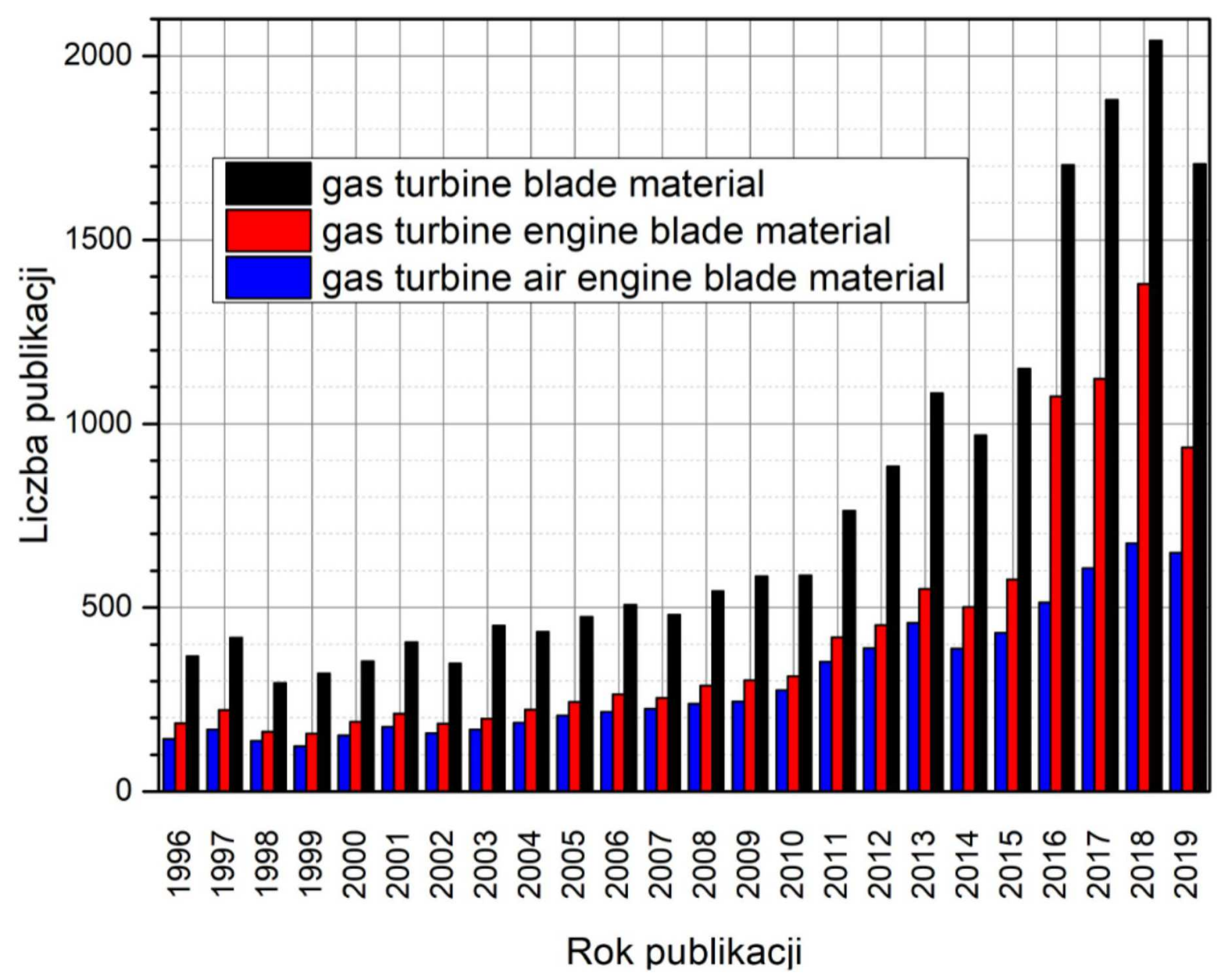

Rys. 1. Zmiana liczby publikacji dotycząca materiałów stosowanych do budowy łopatek turbin gazowych w latach 1996-2019

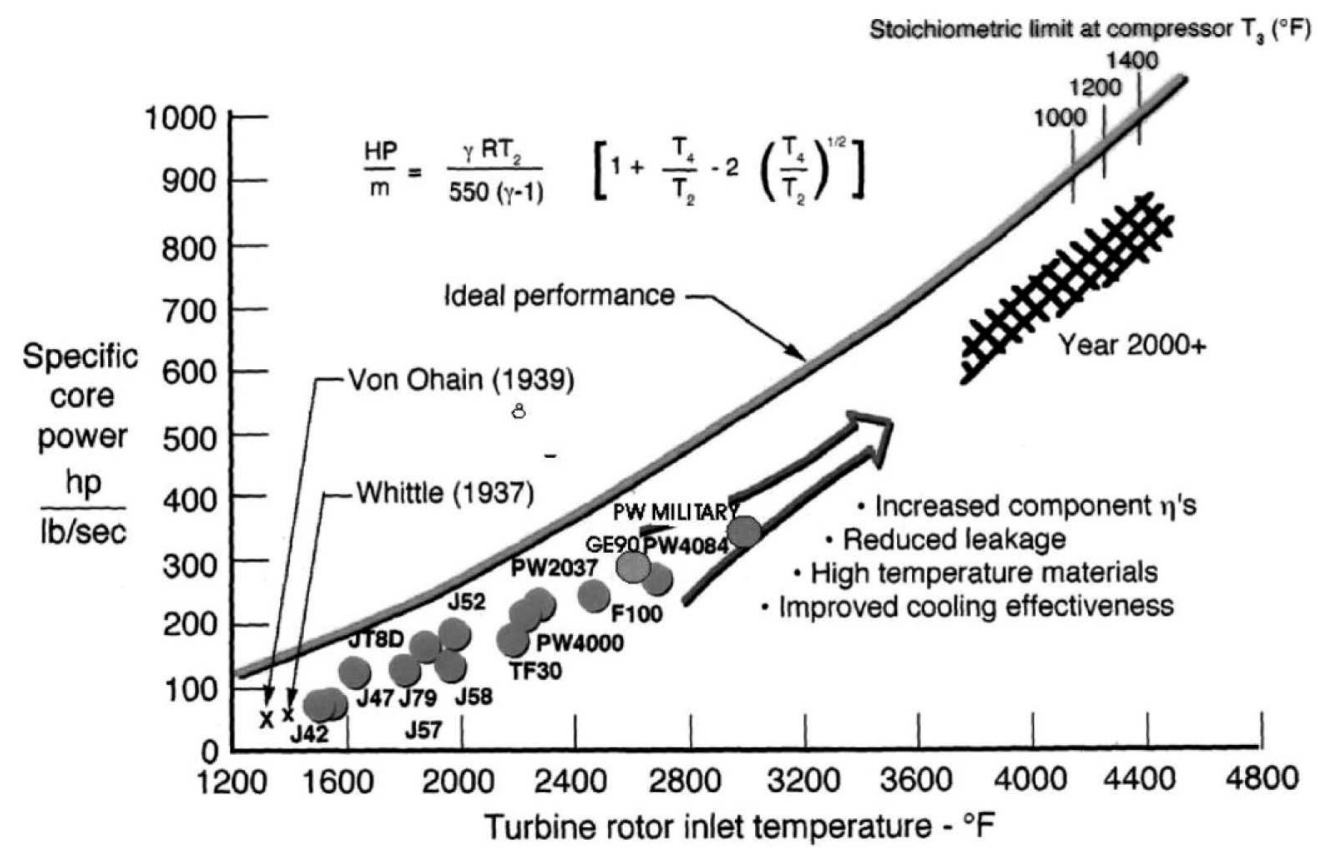

Rys. 2. Wzrost pracy jednostkowej turbiny w funkcji temperatury przed turbiną [2] ${ }^{1}$ 
rozwój tych materiałów ma na celu przede wszystkim wzrost odporności termicznej, umożliwiającej podnoszenie osiągów silników dzięki wzrostowi temperatury gazów spalinowych przed turbiną (rys. 2). Jednakże - jak można zauważyć - możliwości materiałowe, aczkolwiek coraz wyższe z upływem czasu, pozostawiają wciąż wiele do życzenia z punktu widzenia konstruktorów silników.

\section{Stopy na osnowie niklu}

Datujący się od połowy lat czterdziestych XX w. rozwój materiałów żarowytrzymałych na potrzeby zastosowań lotniczych skupiał się głównie na tzw. nadstopach na osnowie niklu lub kobaltu, jednakże ze względu na większe możliwości modyfikacji struktury, a tym samym właściwości użytkowych materiałów na bazie $\mathrm{Ni}$, większym zainteresowaniem naukowców cieszą się stopy na osnowie sieci regularnej centrowanej ściennie (A1) austenitu niklowego (rys. 3).

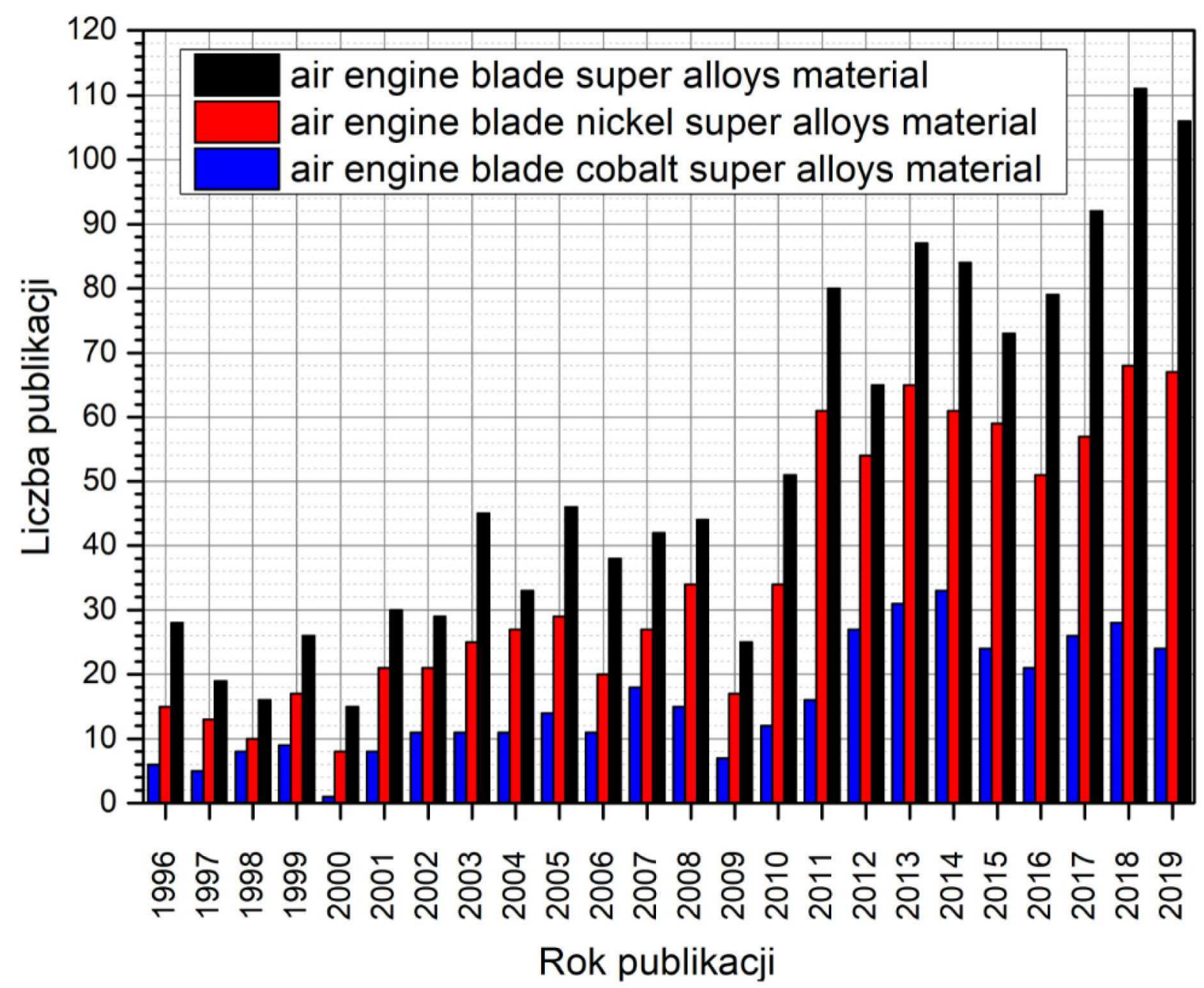

Rys. 3. Porównanie liczby publikacji w bazie Elsevier nadstopów na osnowie niklu i kobaltu

Stopy te w większości przypadków zawierają 10-20\% wag. chromu, do $8 \%$ wag. aluminium z tytanem, 5-15\% wag. kobaltu i małą ilość boru, cyrkonu, magnezu i węgla. Innymi często stosowanymi dodatkami są: molibden, niob i wolfram, które spełniają podwójną rolę, tj. umacniają roztworowo i tworzą węgliki. Chrom i aluminium są konieczne, gdyż poprawiają stabilność powierzchni dzięki tworzeniu tlenków, odpowiednio $\mathrm{Cr}_{2} \mathrm{O}_{3}$ i $\mathrm{Al}_{2} \mathrm{O}_{3}$ [3]. Typowy nadstop charakteryzuje się złożonym składem chemicznym, w skład którego może wchodzić nawet do 15 
różnych pierwiastków chemicznych. Liczba składników wsadowych wpływa na niemal nieograniczone możliwości składu chemicznego implikującego zmiany w budowie fazowej wpływającej z kolei na właściwości użytkowe. W samych Stanach Zjednoczonych, pomimo bardzo silnej konkurencji, na rynku znajduje się ponad sto gatunków nadstopów niklu [4].

Materiały te przechodziły na przestrzeni lat ewolucję technologiczną, sprowadzającą się do modyfikacji stabilności struktury krystalicznej mającej na celu uzyskiwanie jak najwyższych właściwości żarowytrzymałych oraz odporności na pełzanie przy jednoczesnej wysokiej odporności erozyjnej i odporności na kruche pękanie. Początkowo materiały te wytwarzano za pomocą obróbki plastycznej, osiągając dla nadstopów wytwarzanych tą technologią poziom temperatury pracy zapewniający wytrzymałość $140 \mathrm{MPa}$ w czasie 100 godzin równy $900^{\circ} \mathrm{C}$ (rys. 4.) Dalsze zwiększanie parametrów eksploatacyjnych materiałów łopatek można było uzyskać, stosując kanały chłodzacce wewnątrz łopatek turbin (rys. 5.), co spowodowało wzrost temperatury gazów przed turbiną do poziomu ponad $1100^{\circ} \mathrm{C}$. Oczywiście zastosowanie skomplikowanych geometrycznie wewnętrznych kanałów, umożliwiających przepływ czynnika chłodzącego, uniemożliwił jednocześnie stosowanie obróbki plastycznej jako metody wytwarzania łopatek. Od połowy lat pięćdziesiątych XX w. aż do chwili obecnej zdecydowana większość lotniczych łopatek turbinowych wytwarzana jest za pomocą odlewania (rys. 4).

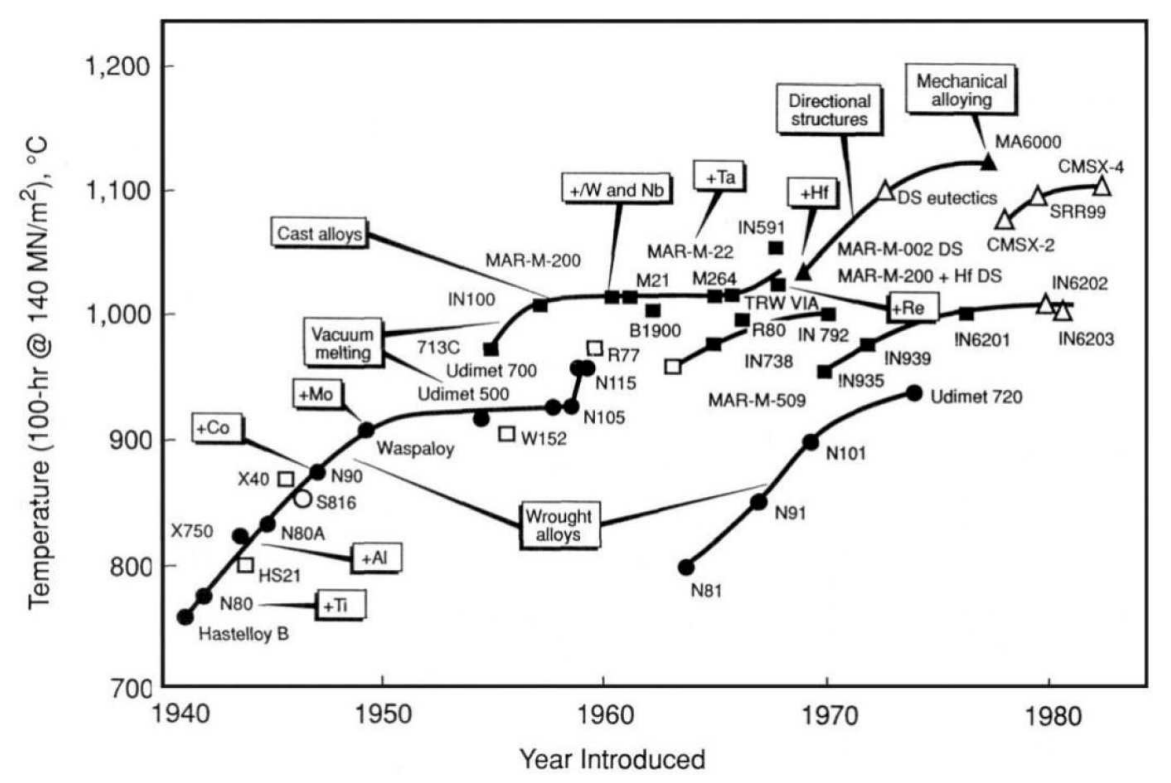

Rys. 4. Wzrost temperatury pracy nadstopów niklowych powiązany z technologią wytwarzania łopatek [4]

Technologiami odlewniczymi i późniejszą obróbką cieplną, polegającą na przesycaniu i starzeniu, uzyskuje się wielofazową strukturę złożoną z osnowy roztworu stałego na bazie niklu $\gamma$ umocnionego wydzieleniami nadstruktury $\gamma^{\prime}$ oraz węglikami. Dobór parametrów obróbki cieplnej, głównie temperatury i czasu przesycania i starzenia, pozwala na sterowanie strukturą udziałem poszczególnych faz, a tym samym wpływa na możliwości sterowania właściwościami użytkowymi materiału, będącymi wypadkową morfologii i liczby poszczególnych składników strukturalnych (rys. 6). Ogólnie procesy metalurgiczne powinno prowadzić się, aby osiągnąć $\mathrm{w}$ strukturze materiału łopatki drobnoziarnistą strukturę ziarnistą z porównywalnym udziałem faz $\gamma$ i $\gamma^{\prime}$ wzmocnioną dyspersyjnymi wydzieleniami węglików rozmieszczonych równomiernie w całej objętości stopu.

Wielofazowa, polikrystaliczna struktura charakteryzuje się quasi-izotropowymi właściwościami materiałowymi, niezależnymi od kierunku przyłożonego obciążenia. Jednakże charakterystyczną cechą struktury krystalicznej jest silna zależność zdolności do przenoszenia naprężeń 


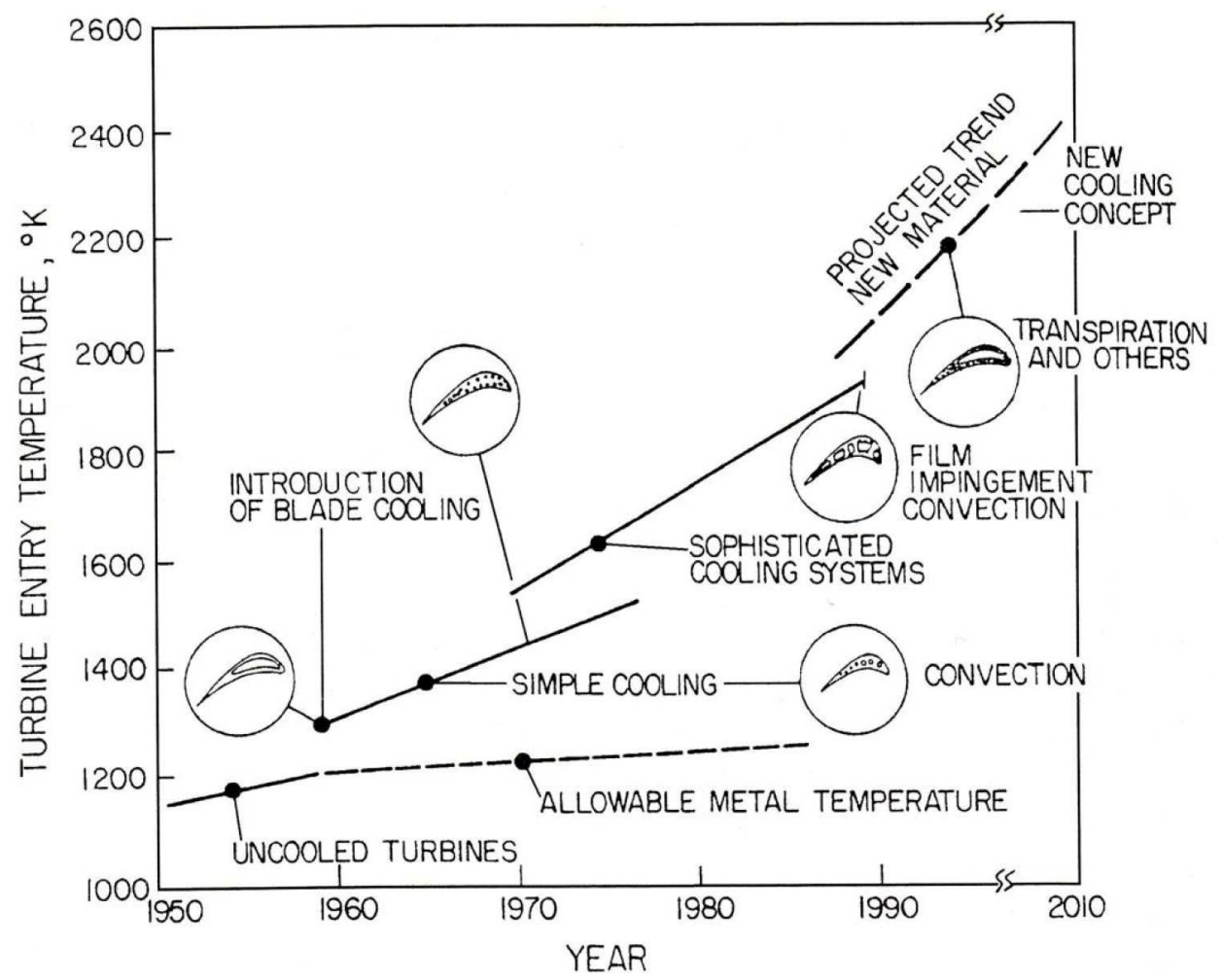

Rys. 5. Wpływ sytemu chłodzenia łopatki turbiny na temperaturę na wejściu do turbiny [11]

(a)

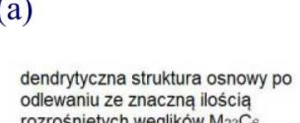
odlewaniu ze znaczną ilością
rozrośniętych wẹglików $\mathrm{M}_{23} \mathrm{C}_{6}$
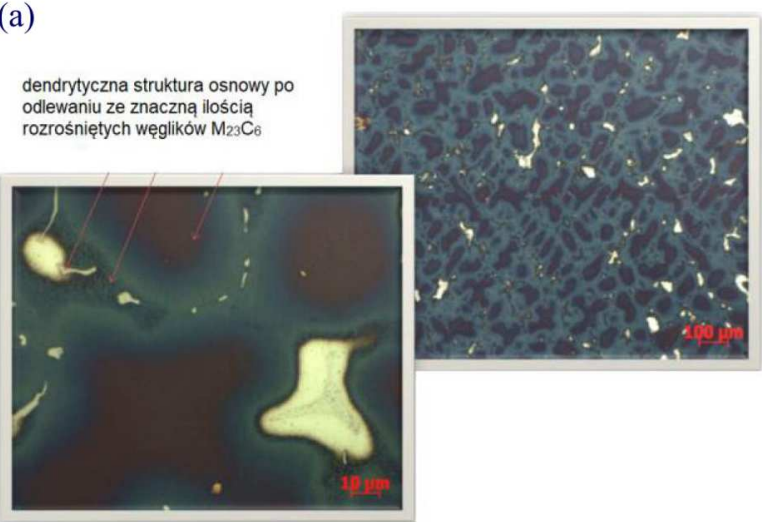

(c)
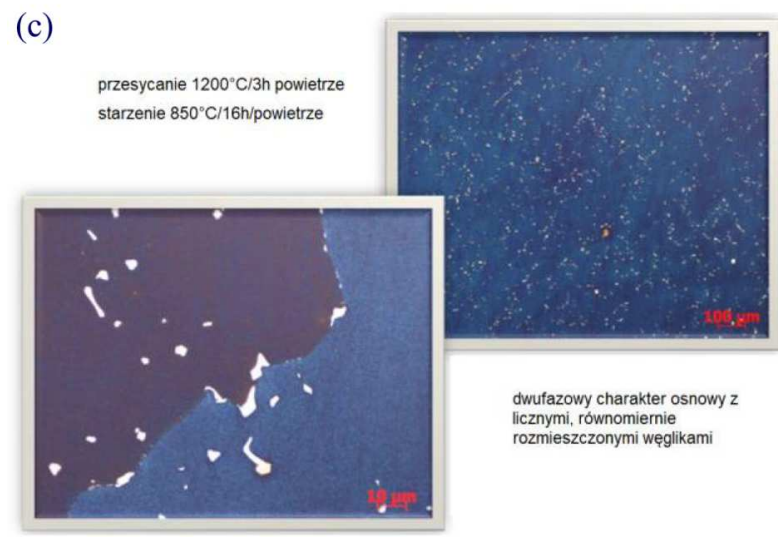

dwufazowy charakter osnowy z rozmieszczonymi weglikar (b)

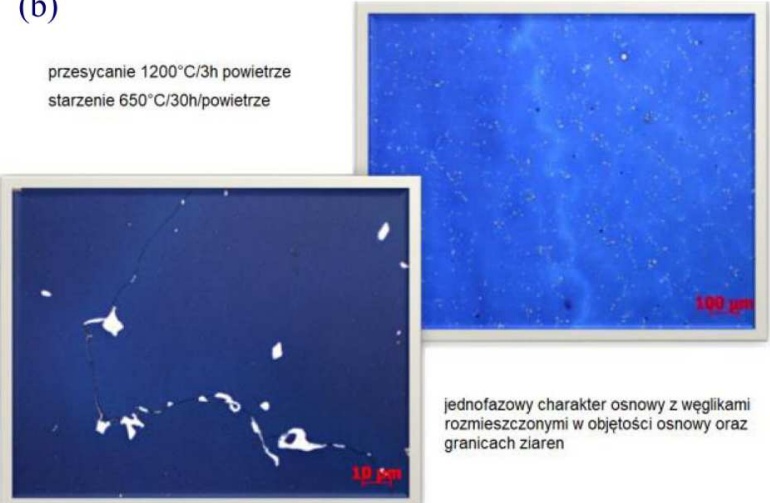

(d)

przesycanie $1200^{\circ} \mathrm{C} / 3 \mathrm{~h}$ powietrze starzenie $1100^{\circ} \mathrm{C} / 8 \mathrm{~h} /$ powietrze

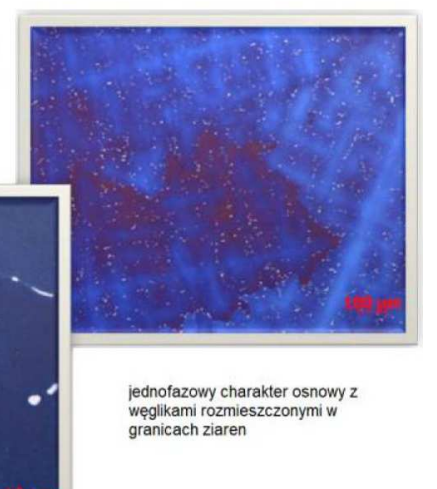

Rys. 6. Możliwości modyfikacji mikrostruktury nadstopu niklu za pomocą parametrów obróbki cieplnej [3] 
mechanicznych lub odkształceń w zależności od kierunku działania sił względem kierunku krystalograficznego struktury materiału obciążonego zewnętrznym wymuszeniem masowym. Na podstawie wyników badań rosyjskich monokrystalicznych stopów ZhS32 i ZhS36 zamieszczonych w pracy [5] można zauważyć, iż odkształcenie materiału próbki zorientowanej wzdłuż kierunku $\langle 001\rangle$ poddanej obciążeniu cyklicznie zmiennemu jest kilkukrotnie mniejsze aniżeli odkształcenie tego samego materiału poddanego obciążeniu wzdłuż kierunku $\langle 011\rangle$ (rys. 7).

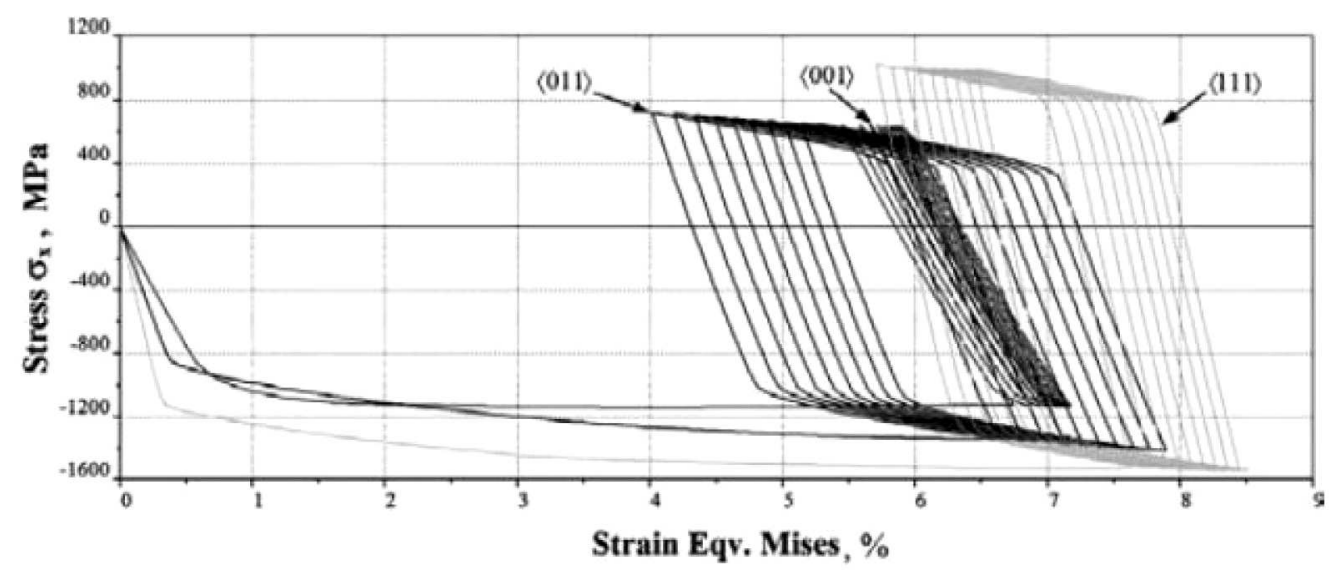

Rys. 7. Wpływ orientacji kryształu na zmiany krzywych $\sigma-\varepsilon$ podczas obciążeń cyklicznie zmiennych [5]

Ta prosta i od dawna znana właściwość materiałów krystalicznych stała się podstawą kolejnego kroku na drodze rozwoju materiału łopatek turbin silników odrzutowych. W celu zwiększenia wytrzymałości, szczególnie na obciążenia masowe pochodzące od sił odśrodkowych, do produkcji łopatek za pomocą topienia i odlewania wprowadzono zabiegi pozwalające na wzrost kryształów kolumnowych o odpowiedniej orientacji krystalograficznej wzdłuż pióra łopatki czy też w ostatnich latach zabiegi wytwarzania łopatek z monokryształów o orientacji krystalograficznej pozwalającej na maksymalne dopuszczalne obciążenia struktury danego materiału (rys. 8).

(a)

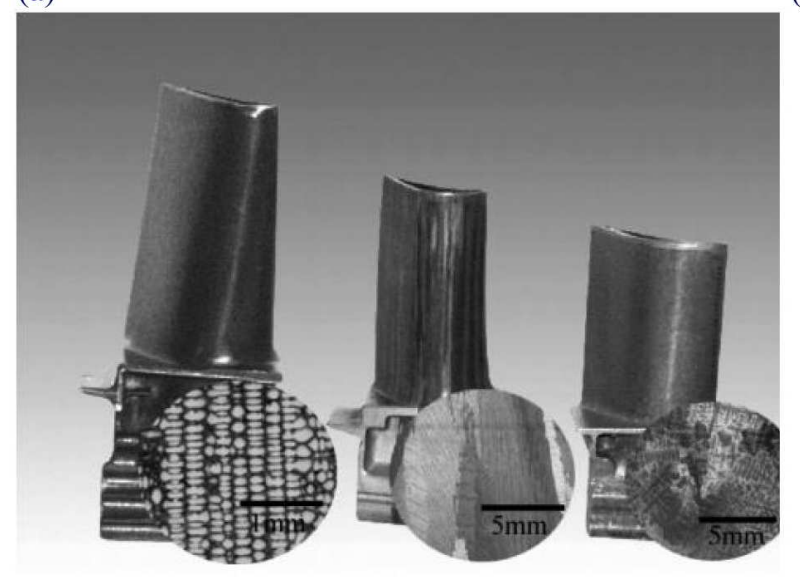

(b)

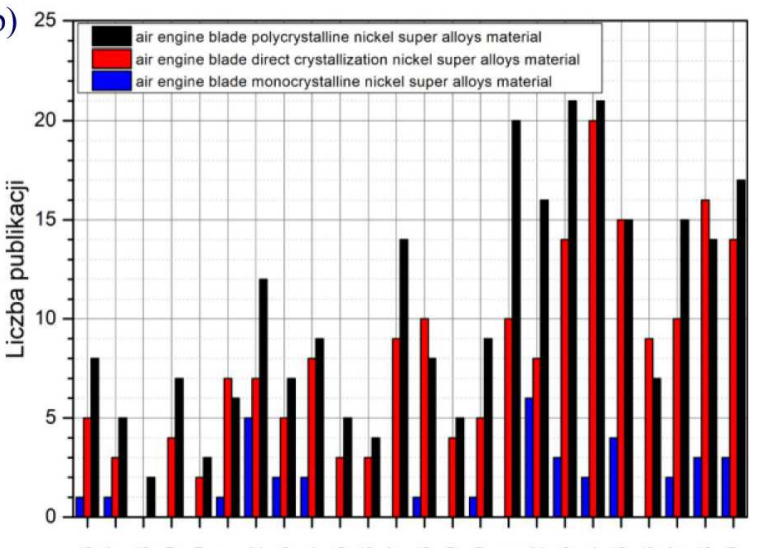

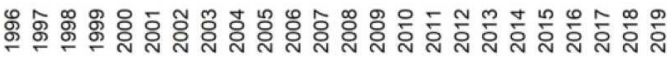

Rys. 8. Łopatki turbin o strukturze (od lewej) monokrystalicznej, kryształów kolumnowych i polikrystalicznej [6] oraz porównanie liczby publikacji w bazie Elsevier dotyczących struktur krystalicznych materiałów łopatek

Ewidentnym dowodem wpływu orientacji krystalograficznej struktury ziarnistej na podniesienie właściwości użytkowych nadstopów niklu używanych do produkcji łopatek turbinowych silników lotniczych jest porównanie właściwości odpowiednika badanego w niniejszej pracy stopu MAR-M 200 po tradycyjnych zabiegach topienia i odlewania oraz obróbki cieplnej tworzącej 
wielofazową drobnoziarnistą strukturę polikrystaliczną, a także tego samego materiału po krystalizacji kierunkowej prowadzącej do utworzenia w materiale łopatki odpowiednio zorientowanych kryształów kolumnowych (tabela 1).

Tabela 1. Porównanie wybranych właściwości stopu MAR-M 200 o strukturze polikrystalicznej i kryształów kolumnowych (na podstawie bazy CES EDU Pack)

\begin{tabular}{|c|c|c|}
\hline Właściwość stopu & $\begin{array}{c}\text { Struktura } \\
\text { polikrystaliczna }\end{array}$ & $\begin{array}{c}\text { Kryształy } \\
\text { kolumnowe }\end{array}$ \\
\hline \hline$E[\mathrm{GPa}]$ & $215-225$ & $125-135$ \\
\hline$R_{02}[\mathrm{MPa}]$ & $755-925$ & $770-950$ \\
\hline$R_{m}[\mathrm{MPa}]$ & $835-1030$ & $900-1100$ \\
\hline$R_{c}[\mathrm{MPa}]$ & $755-925$ & $770-950$ \\
\hline$A[\%]$ & $5-9$ & $7-13$ \\
\hline$H V$ & $300-450$ & $300-450$ \\
\hline$Z_{r j}\left(\right.$ dla $10^{7}$ liczby cykli) $[\mathrm{MPa}]$ & $330-515$ & $360-550$ \\
\hline$K_{I c}[\mathrm{MPa} \sqrt{m}]$ & $120-150$ & $120-150$ \\
\hline max. temp. pracy $\left[{ }^{\circ} \mathrm{C}\right]$ & $815-983$ & $807-987$ \\
\hline
\end{tabular}

Dalszy rozwój materiałów stosowanych na łopatki turbin silników lotniczych zmierza w kierunku domieszkowania materiału łopatek metalami przejściowymi takimi jak hafn, ren czy tantal, których węgliki charakteryzujące się wysoką temperaturą topnienia $\left(\mathrm{Ta}_{4} \mathrm{HfC}_{5}-4215^{\circ} \mathrm{C}\right)$, umacniając strukturę stopu, podnoszą jednocześnie temperature pracy nawet do poziomu $1343^{\circ} \mathrm{C}$ dla stopów utwardzanych dyspersyjnie tlenkami (ODS) [7] wytwarzanych za pomocą metalurgii proszków (rys. 9a). Inną drogą prowadzącą do poszukiwań struktur pozwalających na długotrwałą pracę w wysokich temperaturach jest tworzenia kompozytów o osnowie nadstopów niklowych zbrojonych włóknami wolframowi (rys. 9b), jednakże na chwilę obecną brak jest doniesień o aplikacyjnym zastosowaniu tych materiałów.

(a)

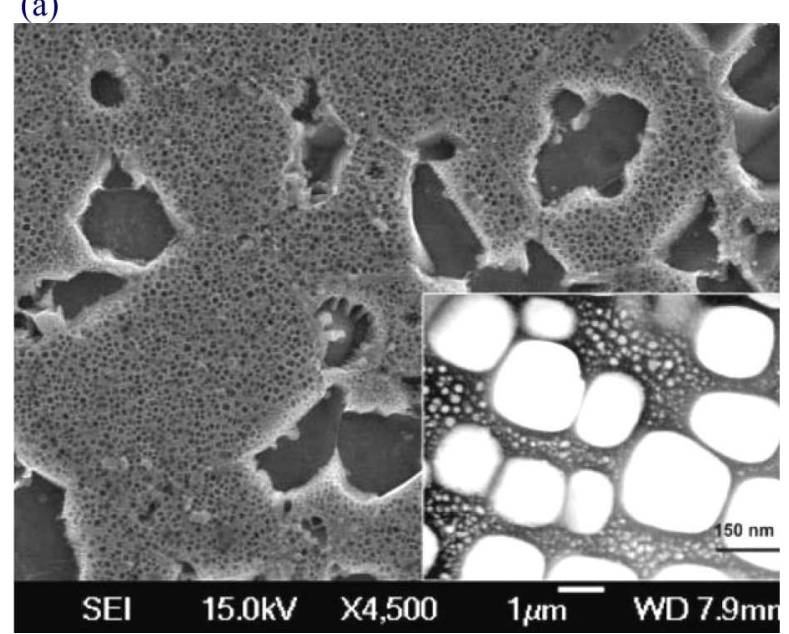

(b)

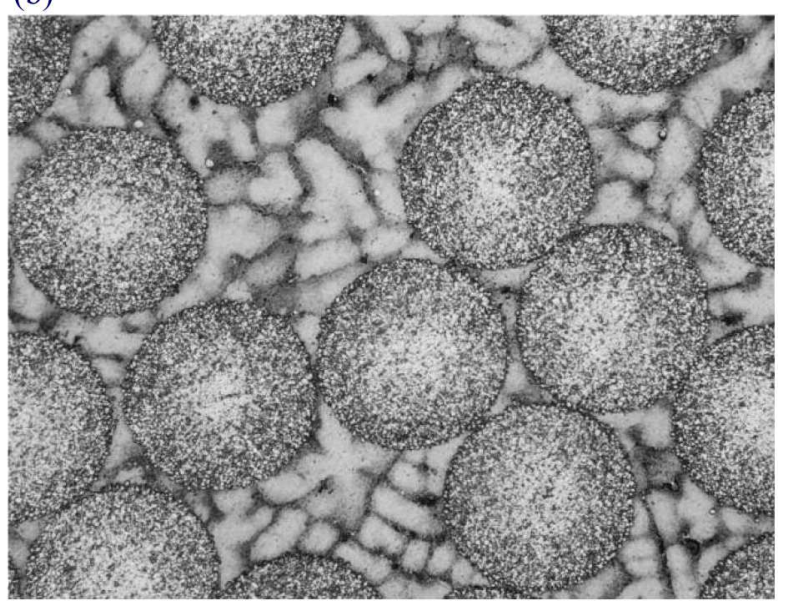

Rys. 9. Ultradrobnoziarnista struktura nadstopu ODS na bazie niklu otrzymana za pomocą metalurgii proszków (a) oraz widok kompozytu na bazie nadstopu niklu wzmacnianego włóknem

wolframowym (b) [8] 


\section{Określenie zamienników materiałowych}

W celu określenia zamienników materiałowych tworzywa konstrukcyjnego użytego do budowy łopatek TWC i TNC silnika RD-33 należy przeprowadzić analizę pośród komercyjnych i ogólnie dostępnych żarowytrzymałych nadstopów.

Dzięki wcześniejszemu określeniu materiału, z jakiego wykonane zostały łopatki turbiny silnika RD-33 oraz znajomości jego właściwości mechanicznych wyznaczonych w badaniach materiałowych, możliwy jest dobór zamienników materiałowych o lepszych właściwościach użytkowych, głównie wytrzymałościowych. Do tego celu użyty został program CES EduPack. Program ten jest jedną bazą danych materiałów konstrukcyjnych, których dobór można rozpatrywać wielowątkowo, poczynając od ich składu chemicznego, przez właściwości wytrzymałościowe, termiczne, a nawet ekonomiczne.

Doborowi materiału towarzyszy proce projektowania na wszystkich możliwych etapach. Ogromna różnorodność dostępnych materiałów sprawia jednak, iż wybór jednego, konkretnego materiału jest często procesem bardzo złożonym. Rozwijająca się standaryzacja umożliwia wprawdzie jego skracanie, ale z drugiej strony nieustannie pojawiają się materiały nowe lepsze stopy, coraz wytrzymalsze polimery i ceramiki, coraz bardziej złożone kompozyty. Projektant potrzebuje więc dodatkowych wskazówek pomagających mu poruszać się po tym labiryncie rożnych możliwości. Wskazówkami tymi są ograniczenia, jakie w każdym ze stadiów procesu projektowego stawia się przy wyborze materiału i jakie powstają jako rezultat optymalizacji właściwości użytkowych i kosztów wyrobu. Pierwsze ograniczenia, takie jak: temperatura pracy, środowisko itp., narzuca się już w projekcie wstępnym. Mieszcząca się w nich grupa materiałów kandyduje się do następnego stadium. Zawężanie tej listy materiałów wymaga teraz zastosowania jakichś technik optymalizacji. Problem nie polega już na tym, który materiał spełnia wymagania, ale który spełni je lepiej. Pojawia się konieczność iteracji; rzadko kiedy materiał o najlepiej pasujących właściwościach będzie materiałem, który najtaniej można uformować, łączyć i obrobić wykańczająco. Potrzebna jest optymalizacja innego rodzaju - znalezienie kompromisu między właściwościami i kosztami całkowitymi. Tworzenie projektu szczegółowego możliwe jest dopiero wtedy, gdy lista możliwych materiałów dla każdej części jest zredukowana do jednego lub do bardzo niewielu tworzyw. Dane materiałowe są potrzebne na każdym etapie procesu projektowego. Tworząc projekt koncepcyjny, projektant potrzebuje przybliżonych danych dla możliwie największej liczby materiałów. Wszystkie możliwości są jeszcze otwarte: dla jednej opcji najlepszy może być materiał polimerowy, a dla innej metaliczny, pomimo że chodzi o tę samą funkcję. Na tym etapie problemem nie jest dokładność danych, lecz tylko ich przedział i dostępność. Z drugiej strony istnieje potrzeba, by zakres danych był na tyle szeroki, aby pozostawić projektantowi jak największą swobodę w rozpatrywaniu alternatywnych rozwiązań. Przy opracowywaniu projektu ogólnego są potrzebne dane o większym stopniu szczegółowości i dokładności, lecz dla znacznie węższego podzbioru wstępnie wybranych materiałów, które można znaleźć w podręcznikach, poradnikach lub komputerowych bazach danych. W etapie końcowym, tzn. projekcie szczegółowym, wymagana jest jeszcze większa dokładność i szczegółowość, lecz już tylko dla jednego bądź nielicznych materiałów. Takich danych najlepiej szukać w publikacjach wydawanych przez producenta konkretnego materiału. Właściwości takiego materiału mogą różnić się nieco od siebie w zależności, od jakiego są producenta. W fazie projektowania szczegółowego należy zidentyfikować producenta materiału i dane materiałowe pochodzące właśnie od niego oraz używać jego danych do ewentualnych obliczeń. Niekiedy jednak to nie wystarczy i jeżeli część jest wyjątkowo odpowiedzialna (tzn. jej uszkodzenie w takim czy innym sensie mogłoby być katastrofalne), pod rozwagę należy wziąć możliwość wykonania własnego pomiaru krytycznej właściwości na próbce materiału od wybranego producenta. Problem materiałowy nie kończy się z chwilą rozpoczęcia produkcji. Wyroby ulegają uszkodzeniom w czasie eksploatacji. Takie uszkodzenia niosą w sobie cenne informacje. Producent, który nie interesuje się zbieraniem danych o wadach własnego 
produktu, jest nieodpowiedzialny. Prawie zawsze dane takie wskazują na jakiś błąd związany z zastosowanym materiałem. Pewna zmiana w konstrukcji bądź zmiana materiału może tę wadę wyeliminować.
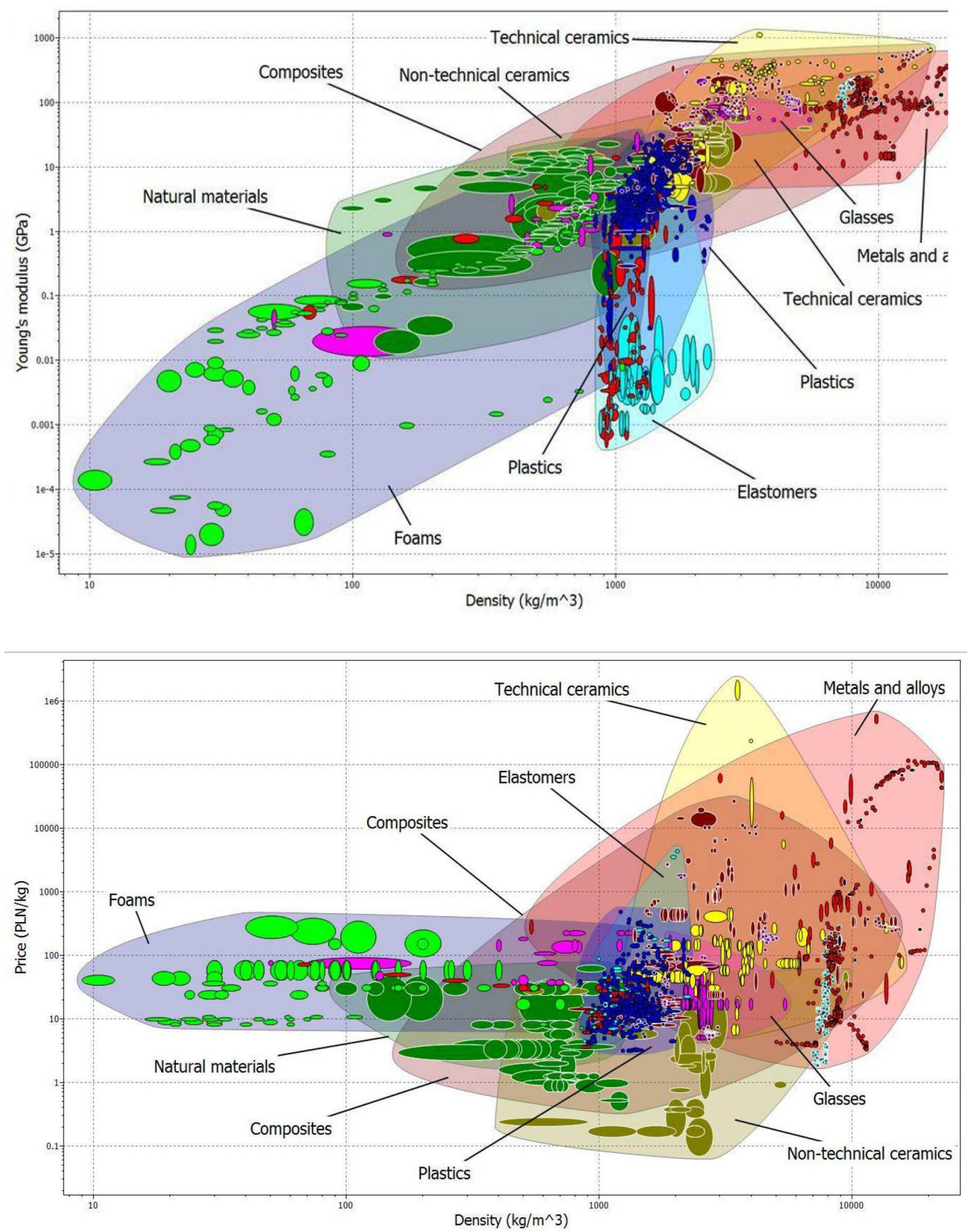

Rys. 10. Grupy materiałów kostrukcyjnych w bazie CES EduPack dostępych do analizy zamienników stopu ŻS6-K (MAR-M 200), z którego wykonane są łopatki turbiny silnika RD-332²

\footnotetext{
${ }^{2}$ Wyniki dotyczące porównania własności materiałów oparte są o oryginalne angielskojęzyczne bazy i dlatego posiadają opis w języku angielskim.
} 
Biorąc pod uwage powyższe wytyczne, analizie ewentualnych zamienników stopu ZS-6U (MAR-M 200), z którego wykonane są łopatki TWC i TNC silnika RD-33, poddano wszystkie materiały konstrukcyjne dostępne w bazie CES EduPack, przyjmując jako wstępne kryterium podstawowy wskaźnik wytrzymałościowy, jakim jest moduł Younga oraz cenę materiału, odniesione do ich gęstości jako parametru priorytetowego w konstrukcjach lotniczych, gdzie dąży się do maksymalnego obniżenia masy własnej poszczególnych elementów statku powietrznego (rys. 10).

Tak szeroka grupa tworzyw konstrukcyjnych - począwszy od pian, poprzez materiały naturalne, szkła, ceramiki, kompozyty, tworzywa sztuczne (polimery), a skończywszy na metalach i ich stopach - dostępna w bazie CES EduPack (około 30 tysięcy różnych współczesnych materiałów użytkowanych w różnych dziedzinach techniki) wymusza zawężenie poszukiwań ewentualnych zamienników stopu ŻS-6U (MAR-M 200) do materiałów o określonych właściwościach użytkowych, a w analizowanym przypadku wyznaczonych na podstawie badań wytrzymałościowych (tabela 2).

Tabela 2. Właściwości wytrzymałościowe materiału łopatki turbiny silnika RD-33

\begin{tabular}{|c|c|c|c|}
\hline Parametr & Minimum & Maksimum & Jednostka \\
\hline \hline$\rho$ & - & 8500 & $\mathrm{~kg} / \mathrm{m}^{3}$ \\
\hline$E$ & 213 & 220 & $\mathrm{GPa}$ \\
\hline$R_{02}$ & 643 & 743 & $\mathrm{MPa}$ \\
\hline$R_{m}$ & 851 & 899 & $\mathrm{MPa}$ \\
\hline$A$ & 5 & 10,38 & $\%$ \\
\hline$H V$ & 337 & 367 & $\mathrm{HV}$ \\
\hline
\end{tabular}

Wprowadzając powyższe dane (oprócz gęstości) do bazy CES EduPack, otrzymano trzy grupy materiałów spełniające warunki wytrzymałościowe określone w tabeli 2 (rys. 11).

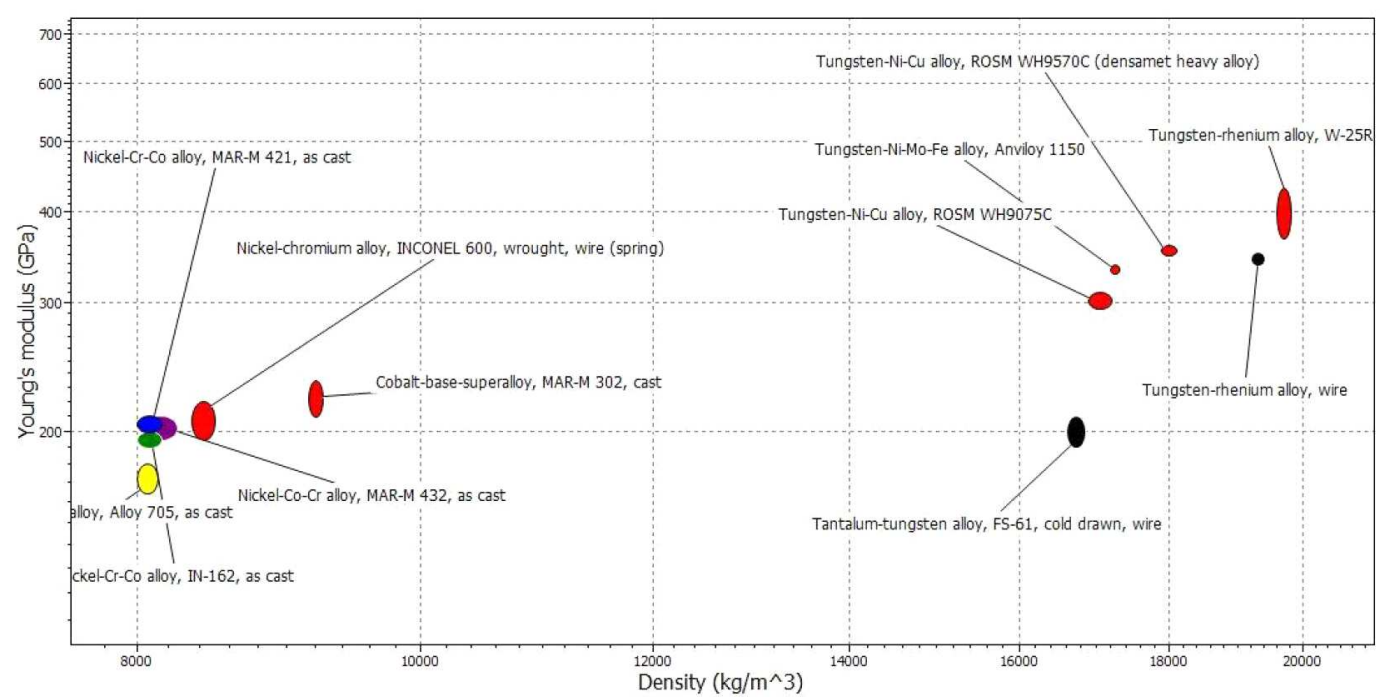

Rys. 11. Tworzywa konstrukcyjne spełniające wymagania wytrzymałościowe określone w tabeli 2

Biorąc pod uwagę wymóg minimalnej masy konstrukcji, determinowanej przez gęstość materiału, dalszej analizie poddano stopy niklu, które posiadają zauważalnie mniejszą gęstość aniżeli stopy wolframu przedstawione na rys. 12.

We współczesnym projektowaniu konstrukcyjnym istotnym czynnikiem jest także cena wytworzenia danego materiału, co przedstawiono na rys. 13. 


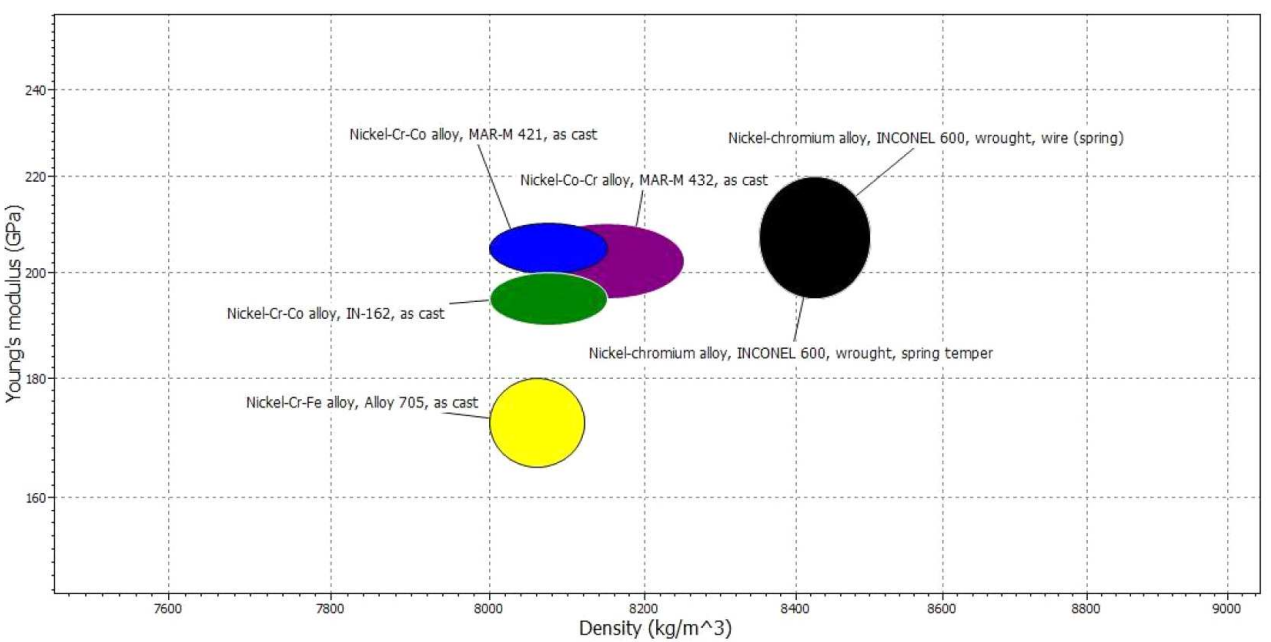

Rys. 12. Nadstopy niklu spełniające wymagania wytrzymałościowe określone w tabeli 2

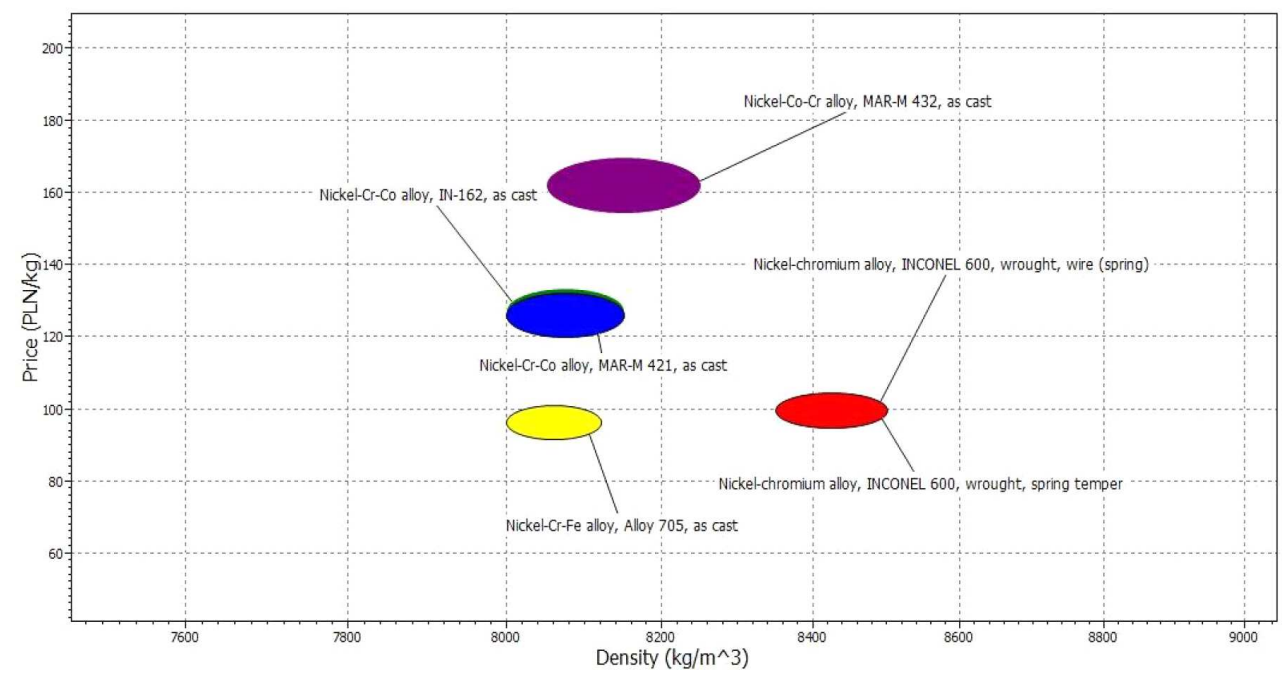

Rys. 13. Cena nadstopów niklu spełniających wymagania wytrzymałościowe określone w tabeli 2

Dalsza analiza ewentualnych zamienników stopu ŻS-6U (MAR-M 200), uwzględniająca przede wszystkim parametry wytrzymałościowe, ze szczególnym uwzględnieniem właściwości zmęczeniowych oraz odporności na kruche pękanie i maksymalnej temperatury pracy, czyli niezwykle istotnych, a może i najważniejszych parametrów materiałów stosowanych na wirujące łopatki sprężarek, wykazała, iż zdecydowanie najlepszymi odpowiednikiem badanego materiału są stopy MAR-M 432 lub MAR-M 421 (rys. 14-22). Stopy te opatentowane przez producenta (Lockheed Martin Corporation) w roku 1995 zostały zaprojektowane specjalnie do produkcji elementów silników odrzutowych za pomocą odlewania: MAR-M 421 przeznaczony do odlewania tarcz turbin, natomiast stop MAR-M 432 jest dedykowany do wykonywania chłodzonych łopatek turbin metodac odlewania.

Właściwości wytrzymałościowe, a w szczególności żarowytrzymałość tych materiałów, pozwalającą na pracę w maksymalnej temperaturze równej $1100^{\circ} \mathrm{C}$, można podnieść przez stosowanie powłok barierowych chroniących materiał łopatki przed cieplnym i erozyjnym oddziaływaniem strumienia gazów spalinowych. Przykładowo, badania przeprowadzone na stopie ŻS-6U pokrytym różnymi warstwami i bez warstw [10] wykazały, iż w każdym przypadku, niezależnie od rodzaju zastosowanej powłoki, zwiększają się naprężenia potrzebne do inicjacji rozwoju kruchego pękania w materiale łopatki. Jak można zaobserwować na rys. 23, dla materiału bez pokrycia proces pękania rozpoczyna się przy naprężeniach rzędu $300 \mathrm{MPa}$, podczas gdy aluminiowo- 


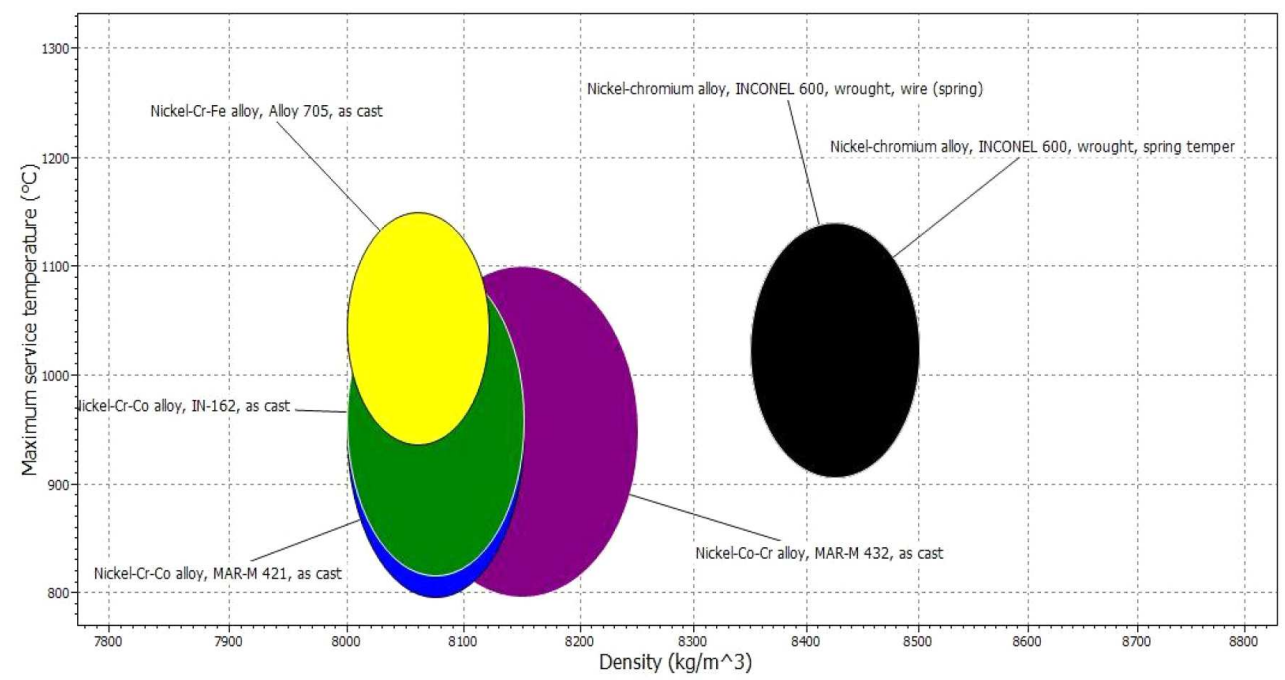

Rys. 14. Maksymalna temperatura pracy nadstopów niklu spełniających wymagania wytrzymałościowe określone w tabeli 2

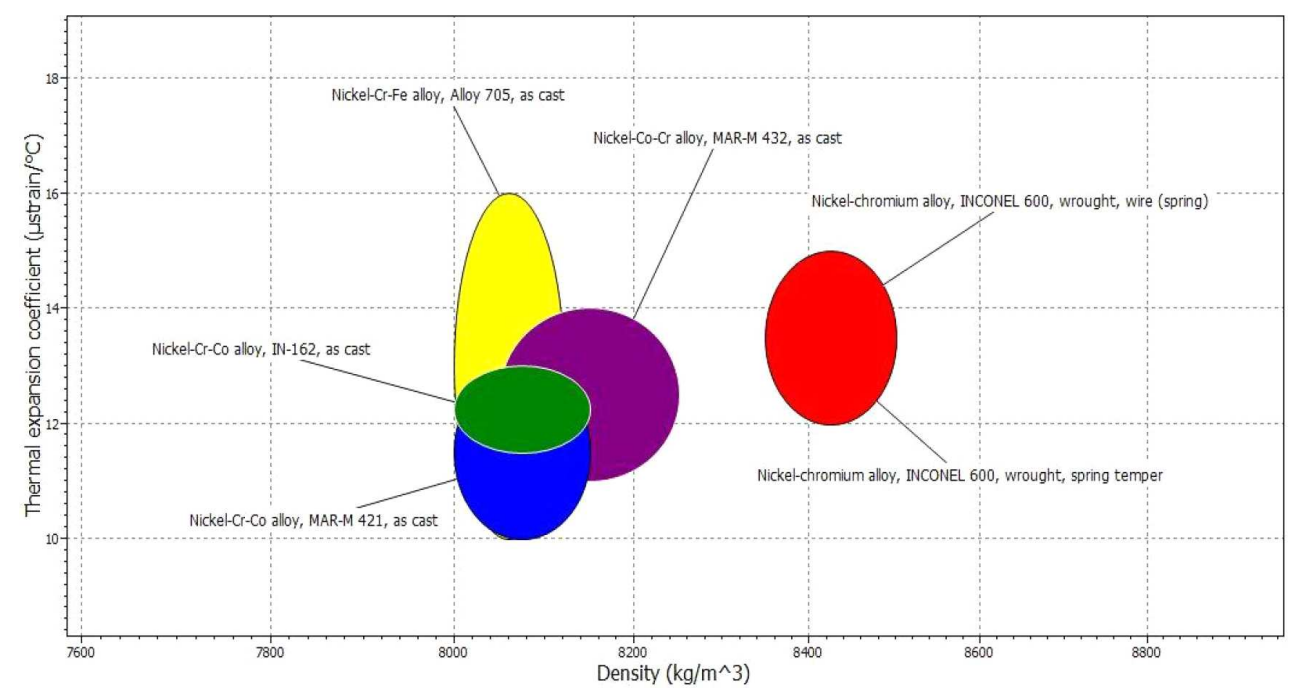

Rys. 15. Współczynnik rozszerzalności cieplnej nadstopów niklu spełniających wymagania wytrzymałościowe określone w tabeli 2

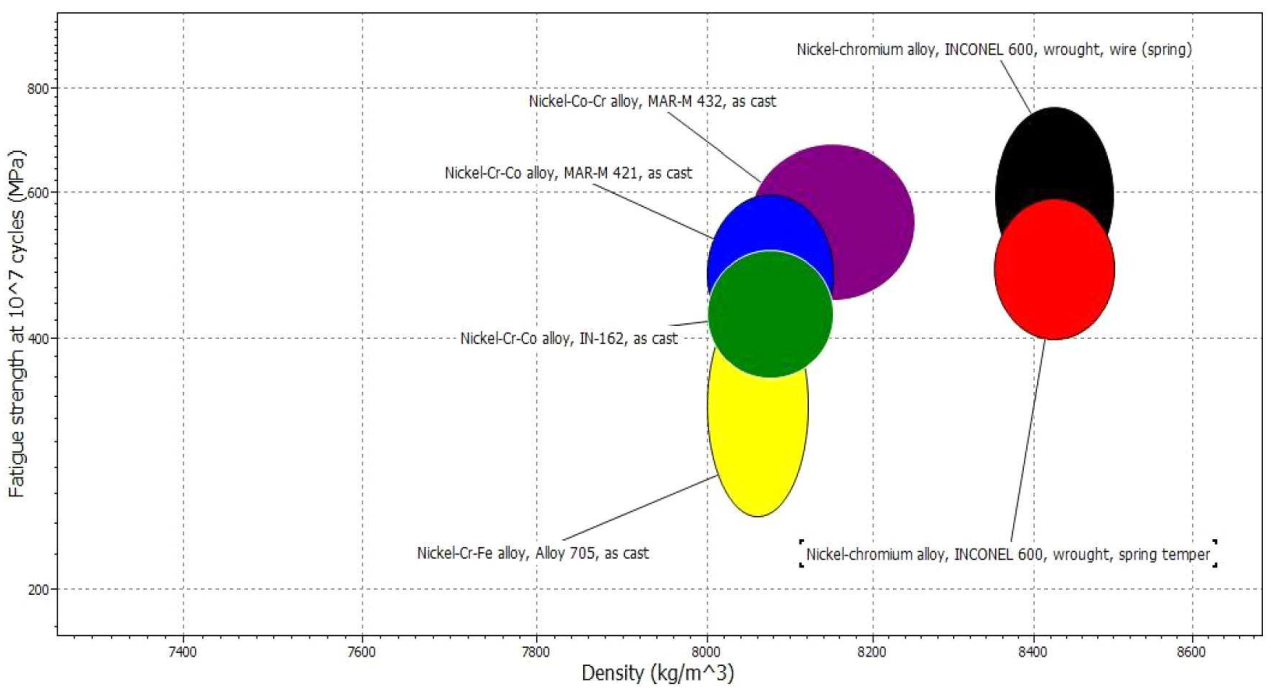

Rys. 16. Wytrzymałość zmęczeniowa nadstopów niklu spełniających wymagania wytrzymałościowe określone w tabeli 2 
Materiałowe tendencje rozwojowe topatek turbin silników lotniczych...

87

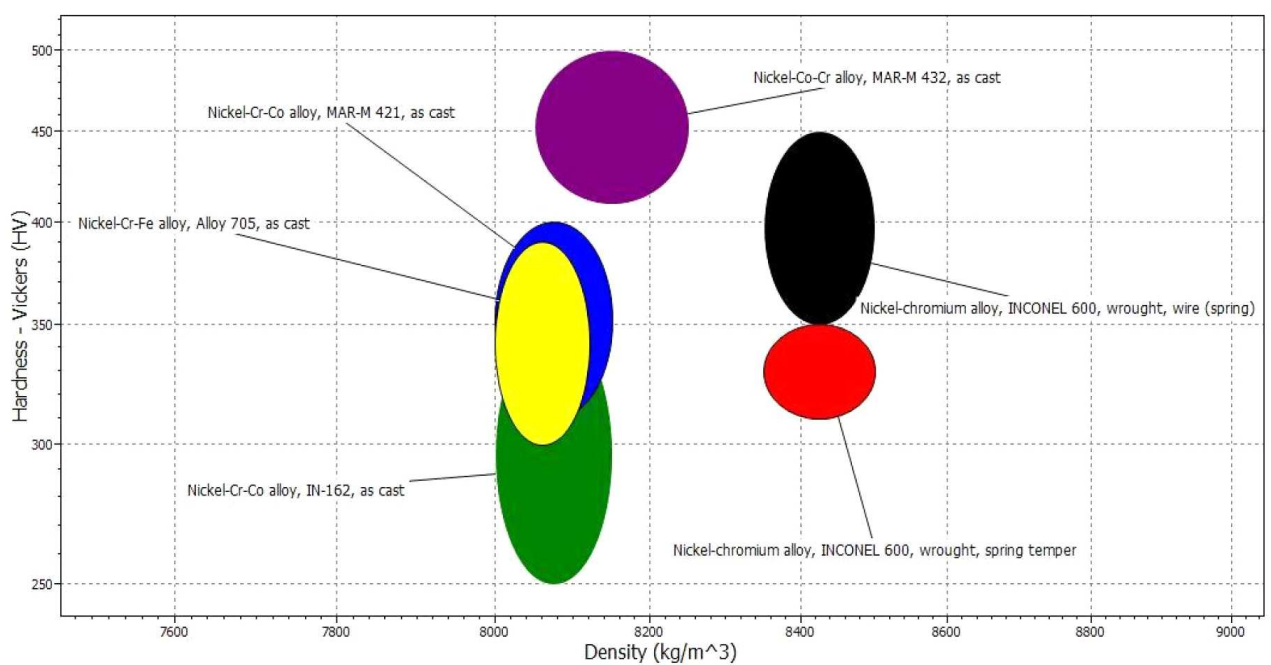

Rys. 17. Współczynnik intensywności naprężeń nadstopów niklu spełniających wymagania wytrzymałościowe określone w tabeli 2

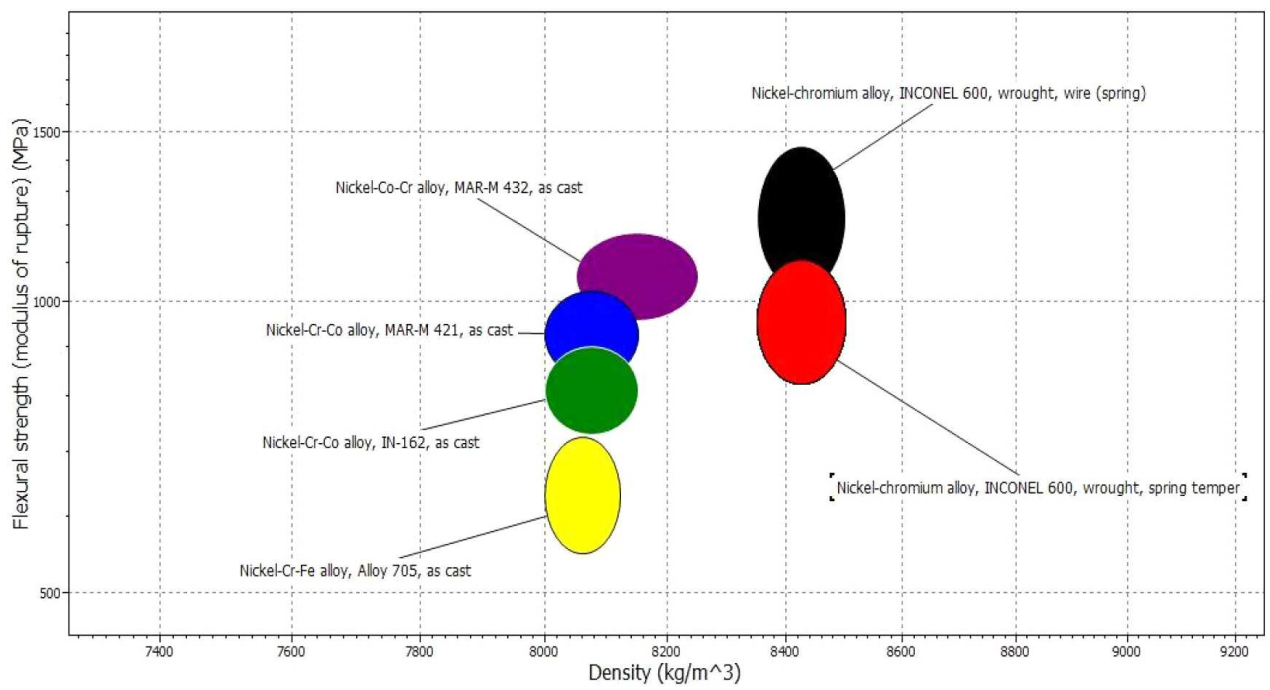

Rys. 18. Wytrzymałość na zginanie nadstopów niklu spełniających wymagania wytrzymałościowe określone w tabeli 2

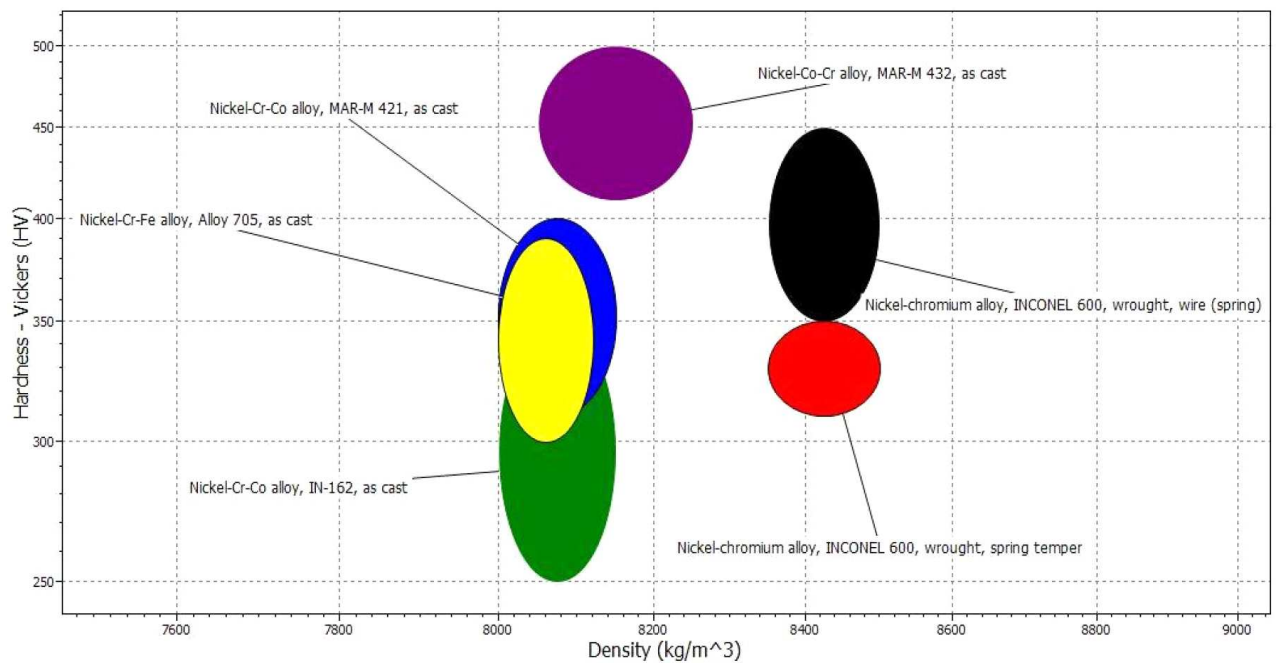

Rys. 19. Twardość nadstopów niklu spełniających wymagania wytrzymałościowe określone w tabeli 2 


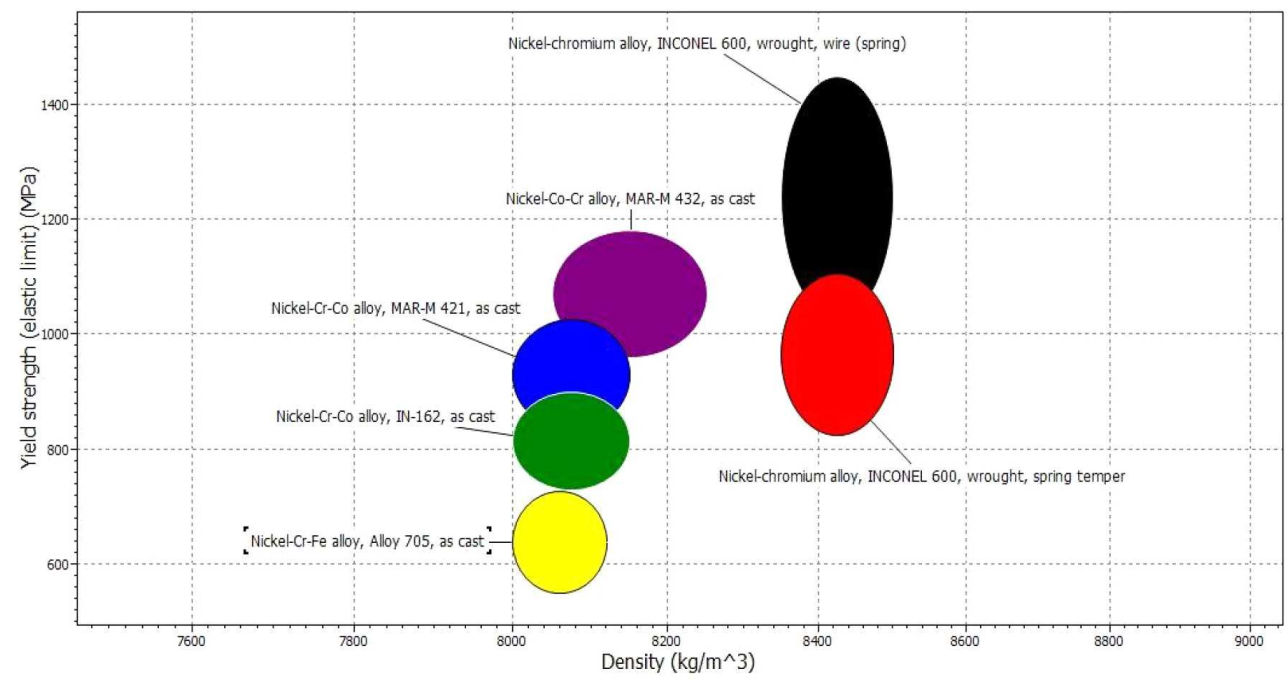

Rys. 20. Granica plastyczności nadstopów niklu spełniających wymagania wytrzymałościowe określone w tabeli 2

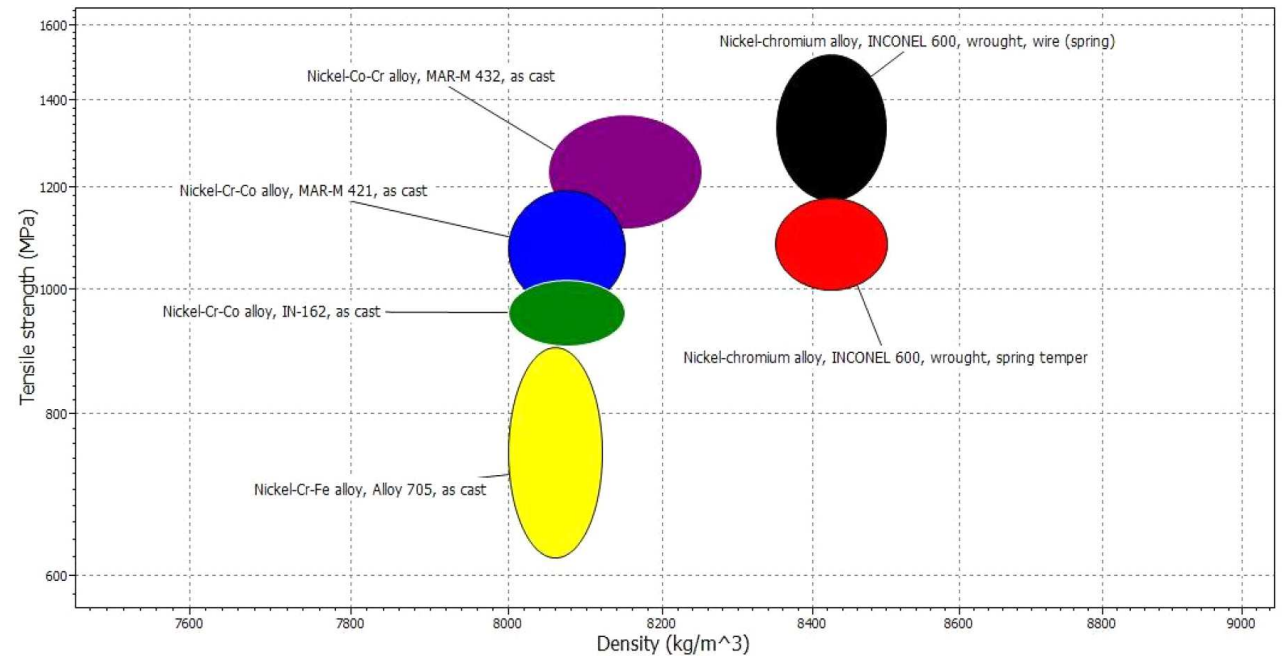

Rys. 21. Wytrzymałość na rozciąganie nadstopów niklu spełniających wymagania wytrzymałościowe określone w tabeli 2

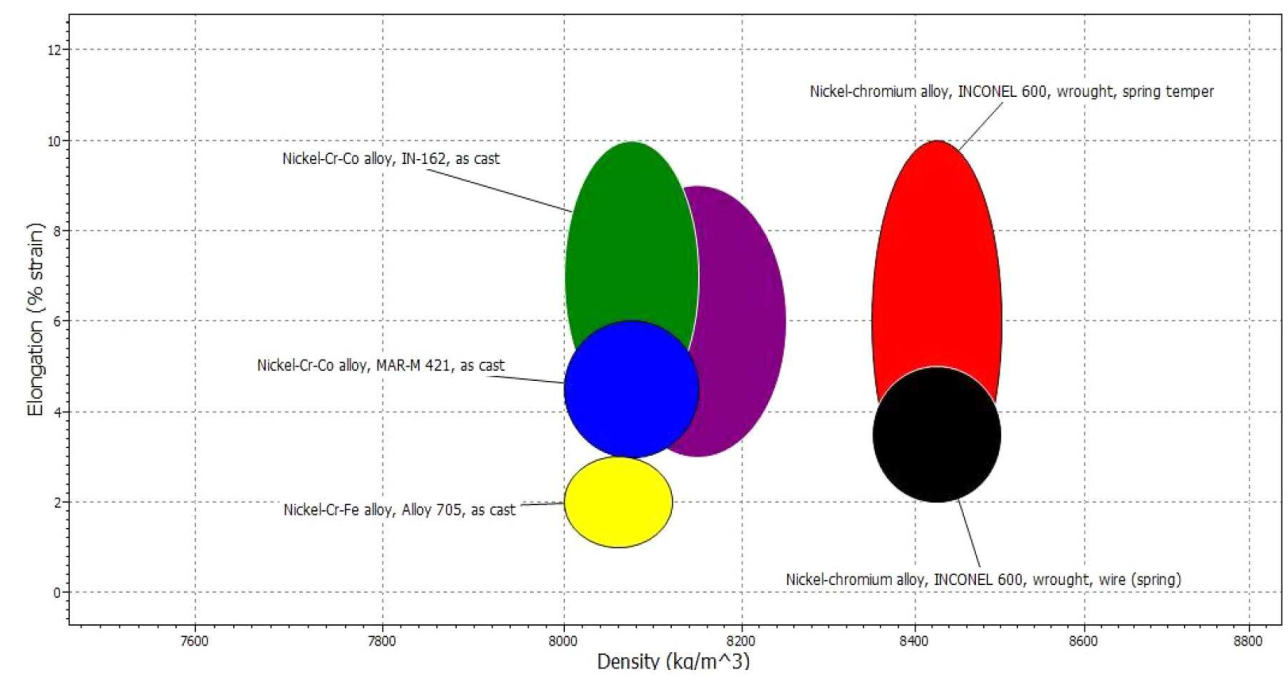

Rys. 22. Wydłużenie nadstopów niklu spełniających wymagania wytrzymałościowe określone w tabeli 2 


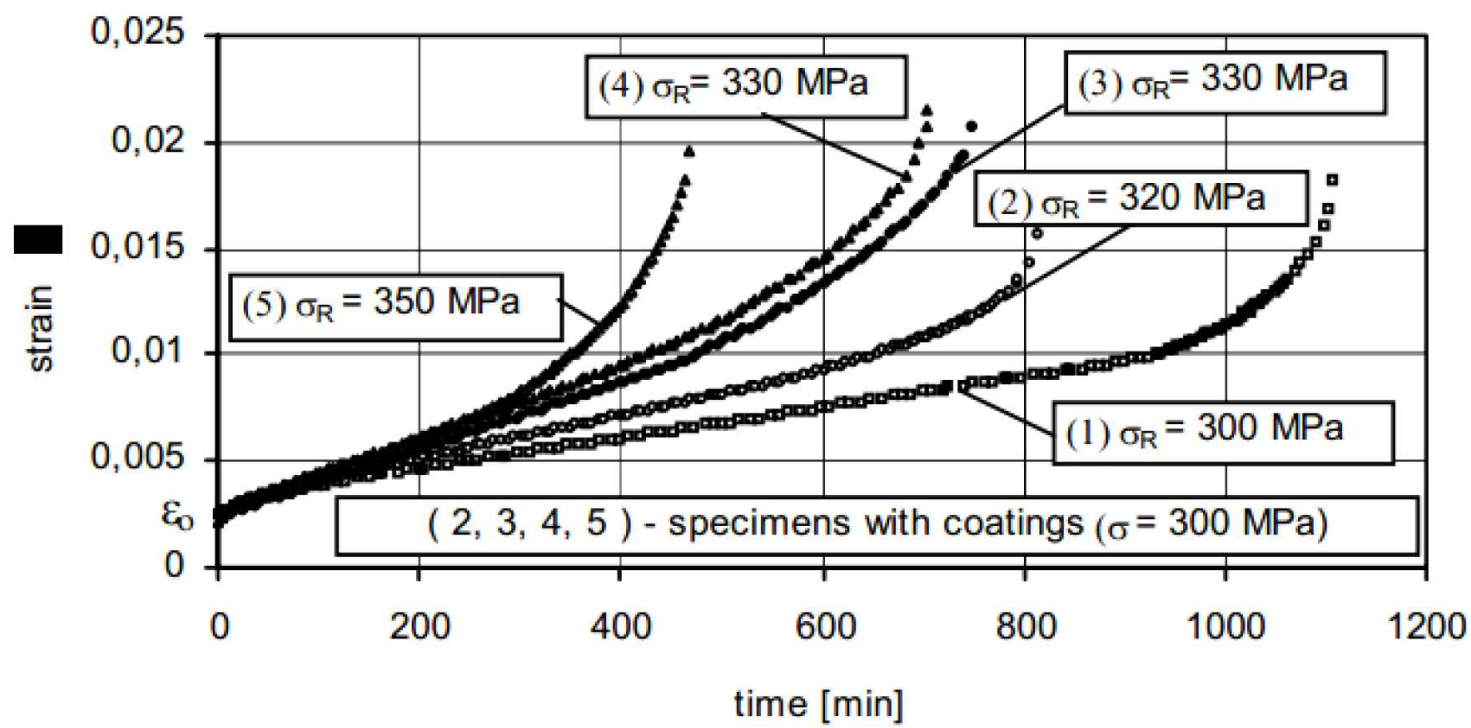

Rys. 23. Naprężenia powodujące kruche pękanie stopu ŻS-6U pokrytego powłokami barierowymi (próbki 2,3,4,5) oraz niepokrytego powłoką ochronną (próbka 1) [10]

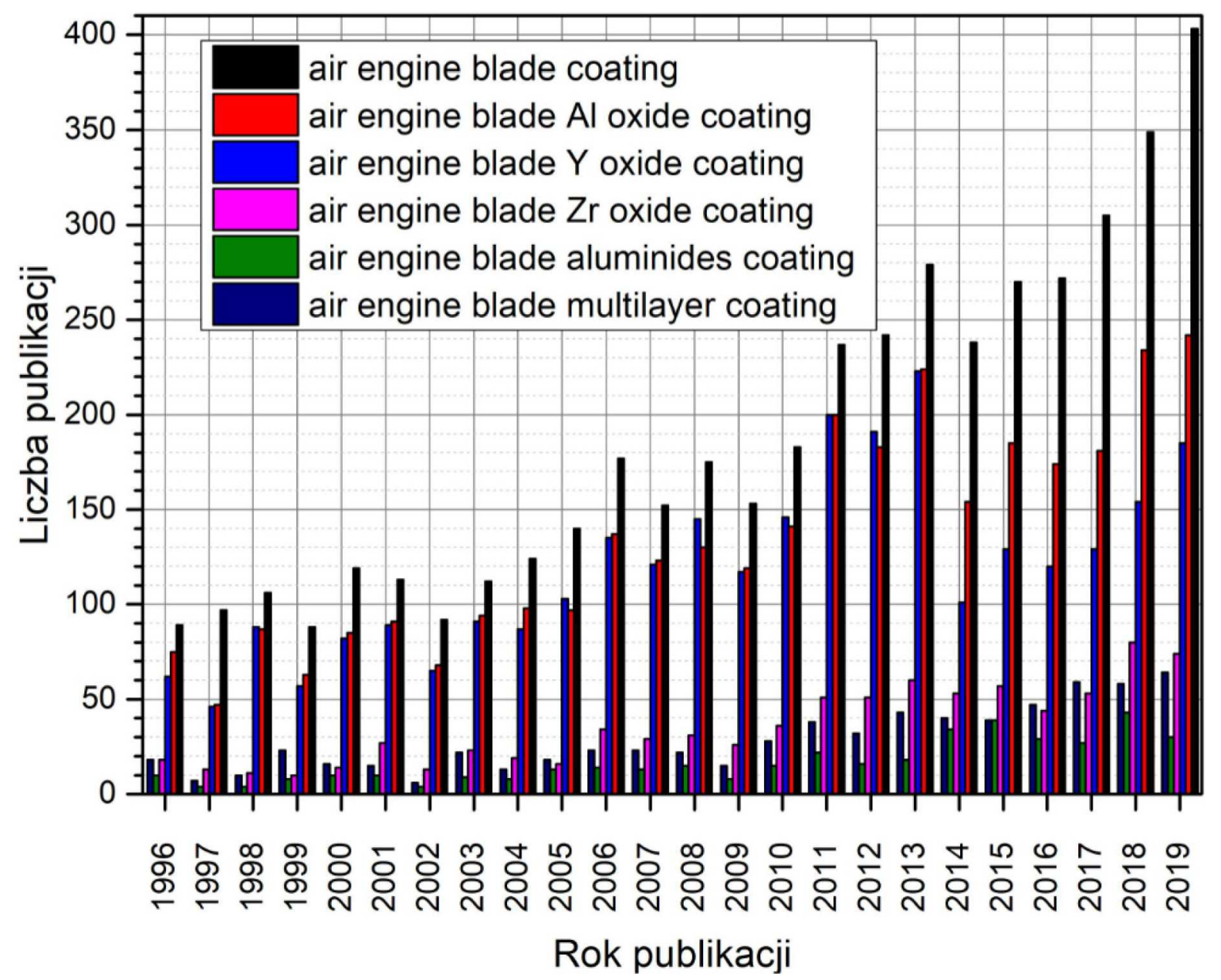

Rys. 24. Porównanie liczby publikacji w bazie Elsevier dotyczących powłok barierowych stosowanych na łopatkach turbin silników odrzutowych 
krzemowa warstwa podnosi naprężenia do poziomu nawet $350 \mathrm{MPa}$. Dlatego też konieczność stosowania powłok barierowych stanowi obecnie konieczny wręcz wymóg zabezpieczania materiału łopatek przed oddziaływaniem środowiskowym.

Analizując liczbę publikacji w bazie Elsevier dotycząca powłok barierowych stosowanych na łopatki turbin silników lotniczych, można zauważyć, iż najwięcej prac poświęca się powłokom opartym na tlenkach aluminium lub itru (rys. 24).

Przeprowadzając jednak analizę statystyczną tych publikacji, można zauważyć, iż w stosun$\mathrm{ku}$ do całkowitej liczby analizowanych doniesień literaturowych w ostatnich latach linia trendu posiada najbardziej dynamiczny wzrost nie tylko w przypadku klasycznych, ale ciągle rozwijanych powłok aluminidkowych, ale także dla powłok opartych na tlenku cyrkonu lub dla powłok wielowarstwowych (rys. 25).

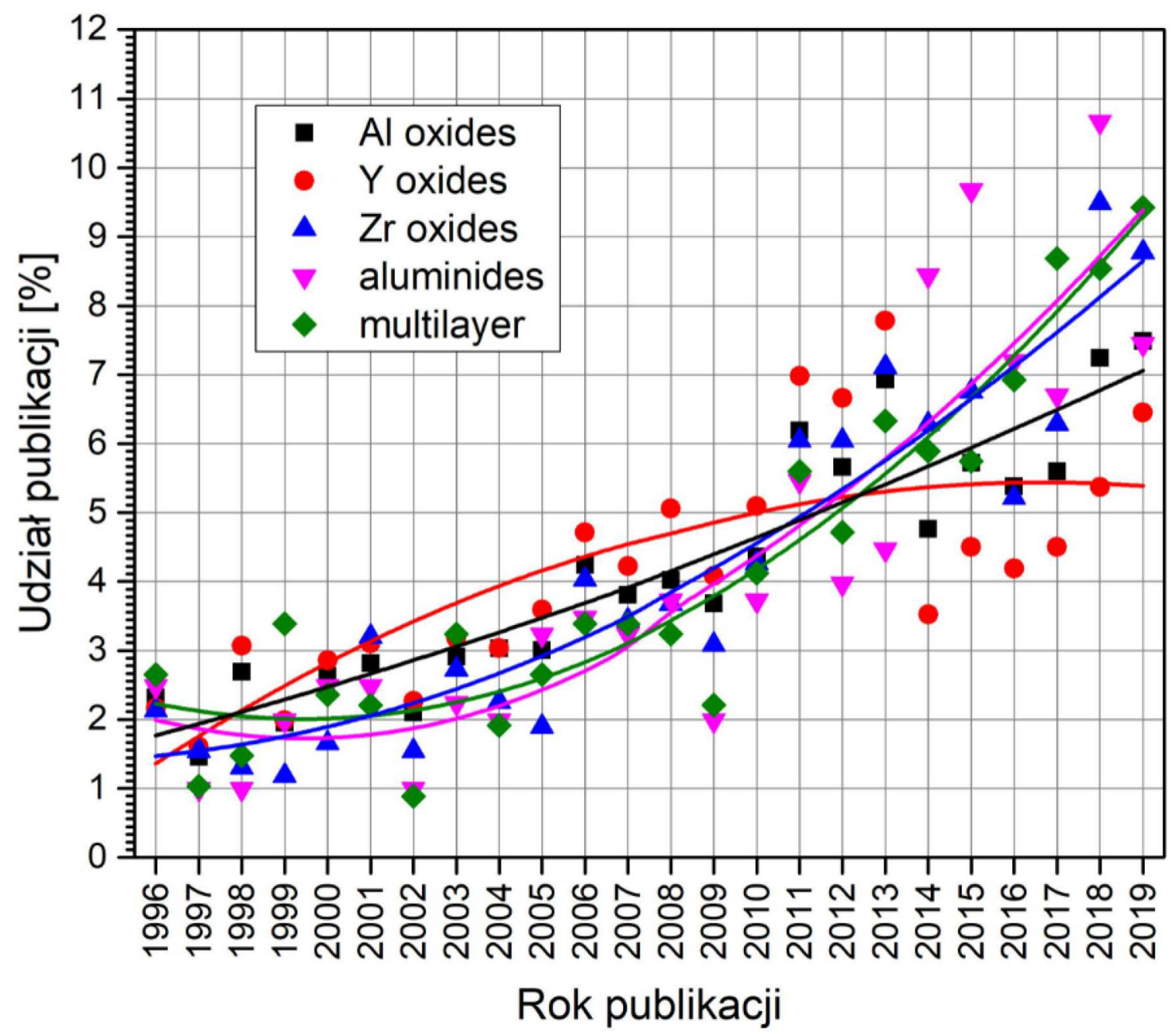

Rys. 25. Statystyczna liczba trendu dotycząca progresu w udziale publikacji dotyczących ochronnych powłok barierowych

Dlatego też wysiłki naukowców, w tym także Polskich, koncentrują się na wytworzeniu wielowarstwowych powłok barierowych o wielofunkcyjnych właściwościach poszczególnych warstw. Przykładem mogą być wyniki badań uzyskane w ramach projektu „Nowoczesne technologie materiałowe stosowane w przemyśle lotniczym, segment nr 10 - Nowoczesne pokrycia barierowe na krytyczne elementy silnika lotniczego" prowadzonego w ramach projektu Innowacyjna Gospodarka przez Konsorcjum Politechniki Rzeszowskiej, Politechniki Śląskiej, Politechniki Warszawskiej 
i Politechniki Lubelskiej. Pokrycia takie pozwalają na podniesienie temperatury gazów przed turbiną nawet do $1500^{\circ} \mathrm{C}$, podnosząc tym samym potencjalne parametry silnika.

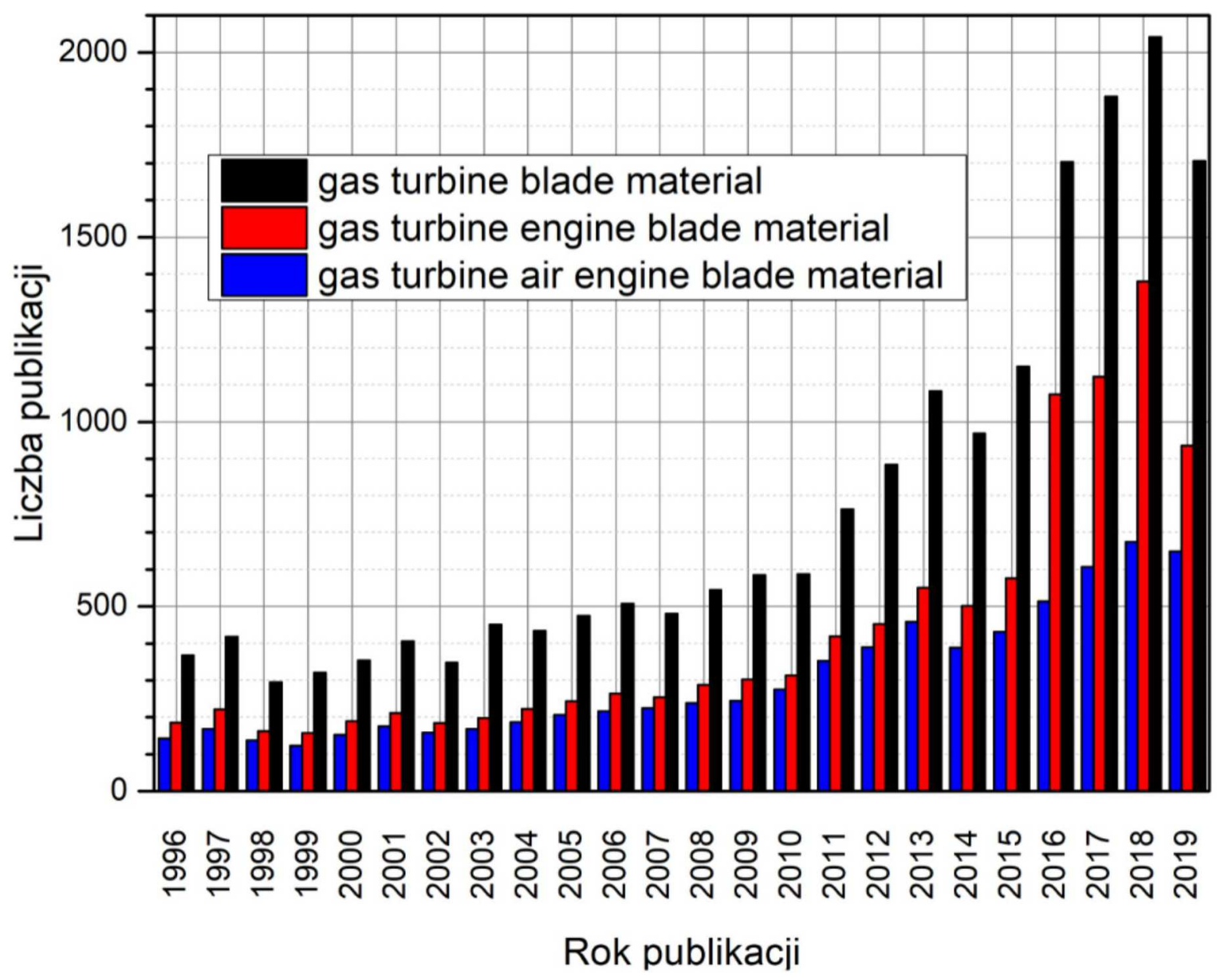

Rys. 26. Schemat i funkcje poszczególnych warstw (a) oraz widok powłoki barierowej (b) wytworzonej na nadstopie niklu [12]

\section{Wnioski}

W wyniku przeprowadzonych badań określono, iż łopatki, zarówno turbiny niskiego jak i wysokiego ciśnienia, zostały wykonane z rosyjskiego nadstopu niklu ŻS6U. Jego odpowiednikiem zachodnim jest stopom MAR-M 200.

Dobór zamienników materiałowych dla tego stopu przeprowadzono w oparciu o bazę danych programu CES EduPack. Po określeniu odpowiednich kryteriów uzyskano listę możliwych zamienników materiałowych, które zostały podzielone na dwie grupy:

- stopy niklu,

- stopy wolframu.

Jednak po uwzględnieniu najważniejszego parametru w lotnictwie, czyli gęstości, która odpowiada za wagę elementów, zakres ten ograniczył się jedynie do grupy, w której znajdowały się nadstopy niklu. Po przeprowadzeniu dalszej analizy okazało się, iż stopami, które w największym stopniu sprostają stawianym im wymaganiom, są dwa stopy opatentowane przez firmę Lockheed Martin Corporation:

- MAR-M 421,

- MAR-M 432. 
Pierwszy z nich został opracowany specjalnie jako stop do odlewania tarcz turbin, natomiast drugi MAR-M 432 przeznaczony jest do wytwarzania łopatek turbin metodą odlewania.

Tabela 3. Porównanie właściwości stopów ŻS6-U oraz stopu MAR-M 432

\begin{tabular}{|l|c|c|}
\hline \multirow{2}{*}{ Właściwość stopu } & \multicolumn{2}{|c|}{ Stop } \\
\cline { 2 - 3 } & ZS6-U & MAR-M 432 \\
\hline \hline Twardość [HV] & $300-450$ & $410-500$ \\
\hline Plastyczność [\%] & $5-9$ & $3-9$ \\
\hline Granica plastyczności [MPa] & $755-925$ & $960-1180$ \\
\hline Wytrzymałość na rozciąganie [GPa] & $835-1030$ & $1120-1370$ \\
\hline Maksymalna temperatura stosowania [ $\left.{ }^{\circ} \mathrm{C}\right]$ & $815-983$ & $797-1100$ \\
\hline
\end{tabular}

W pracy również została przeprowadzona analiza pokryć stosowanych na łopatki, które w sposób dość znaczący zwiększają żarowytrzymałość łopatek turbin. Jak wynika z analizy, najszybciej oraz najchętniej rozwijające się w obecnych czasach są badnia dotyczące powłok opartych na tlenku cyrkonu oraz powłok wielowarstwowych, gdyż zastosowanie ich w silniku pozwala na zwiększenie temperatury przed turbiną nawet do $1500^{\circ} \mathrm{C}$, a tym samym wzrostu sprawności silnika.

\section{Bibliografia}

1. Maciejny A., Metale i stopy metaliczne oraz ich wplyw na rozwój inżynierii materiałowej w Polsce, Polskie i światowe osiągnięcia nauki, Fundacja im. Wojciecha Świętosławskiego na rzecz wspierania nauki i rozwoju potencjału naukowego w Polsce, http://fundacjarozwojunauki.pl/

2. Koff B.L., Gas turbine technology evolution: a designer's perspective, Journal of Propulsion and Power, 20, 4, July-August 2004

3. Pirowski Z., Uhl W., Wodnicki J., GwiżDż A., JAśkowiec K., Wpływ obróbki cieplnej na strukturę stopu typu Inconel 740, Prace Instytutu Odlewnictwa, LI, 2, 5-22, 2011

4. StęPNiowska E., Wptyw dlugotrwatego wyżarzania na mikrostrukturę i własności stopu Ni-25Mo$8 \mathrm{Cr}$, Rozprawa doktorska AGH, Kraków, 2013

5. Getsov L.B., Semenov A.S., Tikhomirova E.A., Rybnikov A.I., Thermocyclic and staticfailure criteria for single-crystal superalloys of gas-turbine blades, Materials and Technology, 48, $2,255-260,2014$

6. Pollock T.M., Tin S., Nickel-based superalloys for advanced turbine engines: chemistry, microstructure, and properties, Journal of Propulsion and Power, 22, 2, 361-374, 2006

7. Donachie M.J., Donachie S.J., Superalloys - a Technical Guide, 2nd Ed., ASM International, ISBN 0-87170-749-7, 2992

8. Wusatowska-Sarnek A.M., Ghosh G., Olson G.B., Blackburn M.J., Aindow M., Characterization of the microstructure and phase equilibria calculations for the powder metallurgy superalloy IN100, Journal of Materials Research, 18, 11, 2653-2663, 2003

9. Zitnanskya M., ZRnik J., Martinkovic M., Developing processes of property improvement of nickel base superalloys, Journal of Materials Processing Technology, 78 204-209, 1998

10. Cieśla M., SwadźBA L., Cracking processes during creep test of ŻS6U superalloy with aluminium coatings, Journal of Achievements in Materials and Manufacturing Engineering, 17, 1-2,177-180, 2006

11. Han J.-C., Dutta S., EkKad S.V., Gas Turbine Heat Transfer and Cooling Technolog, Taylor \& Francis, New York, 2000

12. https://docplayer.pl/8412420-Nowoczesne-technologie-materialowe-stosowane-w-przemyslelotniczym-nowoczesne-pokrycia-barierowe-na-krytyczne-elementy-silnika-lotniczego.html 


\section{Trends in material development of turbine blades in jet engines in turbofan jet engine RD-33}

This paper analyzes high-temperature super alloys used in production of aircraft gas turbines. Many years of development of these materials aimed at achieving an increase in heat resistance that would allow a boost of the performance of jet engines by increasing the temperature in exhaust gases approaching the turbine. There are some material possibilities (that improve over time) but it is still not enough from the point of view of engine designers. The main goal of this paper is to single out material replacements for construction materials used to build blades of the RD-33 engine. To achieve this, we analyzed many commercial and widely available high-temperature super alloys. Thanks to the previous work of the team, the actual material components of the RD-33 jet engine were established. Armed with knowledge of its mechanical properties discovered in material tests, it is possible to select material replacements with better utility properties, focusing on heat resistance. CES EduPack program was used to achieve this goal. 